Akademik Siyer Dergisi / Journal of Academic Sirah

e-ISSN: $2687-5810$

Y11 / Year: 2, Sayı / Issue: 4, Sayfa / Page: 73-94

\title{
Hz. Muhammed'in Yetişmesinde Etkili Olan Bazı Kişiler*
}

Some People Who Were Active in The Prophet Muhammad's Upbringing

\author{
Mehmet Eser \\ eser.mehmet26@gmail.com \\ orcid.org/0000-0002-4489-9463
}

\begin{abstract}
Adnan Adıüzel
Prof. Dr., Eskişehir Osmangazi Üniversitesi İlahiyat Fakültesi, İslam Tarihi Ana Bilim Dalı Prof. Dr., Eskisehir Osmangazi University Faculty of Teology, Department of Islamic History

$$
\begin{gathered}
\text { Eskişehir / Turkey } \\
\text { adiguzela63@gmail.com }
\end{gathered}
$$$$
\text { orcid.org/0000-0002-4818-4051 }
$$

\section{Makale Bilgisi / Article Information}

*Bu makale "Risalet öncesi Hz. Muhammed'in Hayatına Etki Eden Bazı Kadınlar" (Eskişehir Osmangazi Üniversitesi SBE, Eskişehir 2019) adlı yüksek tezinden üretilmiştir.

This article is produced from master's thesis named "Some Women Effecting the Life of Prophet

Muhammad before the Prophecy" (Eskisehir Osmangazi University SBE, Eskişehir 2019).

Makale Türü: Araştırma Makalesi / Article Type: Research Article

Geliş Tarihi: 10 Mart 2021 / Date Received: 10 March 2021

Kabul Tarihi: 4 Mayıs 2021 / Date Accepted: 4 May 2021

Yayın Tarihi: 30 Haziran 2021 / Date Published: 30 June 2021

Yayın Sezonu: Haziran 2021 / Pub Date Season: June 2021

Atıf: Eser, Mehmet-Adıgüzel, Adnan. “Hz. Muhammed'in Yetişmesinde Etkili Olan Bazı Kişiler”. Akademik Siyer Dergisi 4 (Haziran 2021), 73-94.

Citiation: Eser, Mehmet-Adıgüzel, Adnan. "Some People Who Were Active in The Prophet Muhammad's Upbringing". Journal of Academic Sirah 4 (June 2021), 73-94.

https://doi.org/10.47169/samer.894366

İntihal: Bu makale, iTenticate yazılımınca taranmıştır. İntihal tespit edilmemiştir.

Plagiarism: This article has been scanned by iTenticate. No plagiarism detected.

web: http://dergipark.gov.tr/samer e-mail: akademiksiyerdergisi@ksu.edu.tr

Copyright (C) Published by KSÜ Siyer-i Nebi Araştırmaları Uygulama ve Araştırma Merkezi

KSU Sirah Researches Application and Research Center

Kahramanmaraş 46100 Turkey

Bütün hakları saklıdır. / All right reserved. 


\title{
Öz
}

Bu çalışmada, çocukluk döneminden itibaren Hz. Muhammed'in yetişmesine önemli katkıları olan bazı şahsiyetler ile onun ilişkisi ele alınmıştır. Bu anlamda çalışmada öne çıkan şahsiyetlerden Hz. Muhammed'in annesi Âmine, dadısı Ümmü Eymen, sütannesi Halime, dedesi Abdulmuttalip, amcası Ebû Talib ve onun eşi Fatıma üzerinde durulmuştur. Bu kişiler Hz. Muhammed'in doğumundan evlilik dönemine kadar onun en yakınında bulunmuşlar ve onun yetişmesine büyük bir destek sağlamışlardır. Hz. Muhammed bu kişilerin yanında hayata başlamış, ilk eğitimini onların yanında almıştır. Bebekliğinden itibaren evleninceye kadar hayatını onların gözetiminde sürdürmüştür. Dolayısıyla Hz. Muhammed'in üstün ahlakının temelleri bu kişiler yanında oluşmuştur. Allahu Teâlâ Hz. Muhammed'in sahip olduğu yüce ahlakı ona bu kişiler eliyle kazandırmıştır. Makalede Peygamberimizin yetişmesinde önemli katkıları olan yakınlarının ahlaki ve insanî özellikleri ortaya konmaya çalışılmıştır. Böylece Hz. Muhammed'in ahlakının beslendiği temellerin anlaşılmasına katkı sağlanması hedeflenmektedir.

Anahtar Kelimeler: Siyer, Amine, Ümmü Eymen, Abdülmuttalib, Ebû Talib.

\begin{abstract}
In this study, some personalities who contributed significantly to the upbringing of the Prophet Muhammad (pbuh) from childhood and his relationship were discussed. More specifically, the Prophet Muhammad's mother, Amina Khatun, his nanny Umm Ayman, his nurse Halime, his grandfather Abdulmuttalip, his uncle Abu Talib and his wife Fatima bt. Asad are focused on. These people provided great support to his upbringing and they were closest to the Prophet Muhammad from his birth until his marriage. Prophet Muhammed (pbuh) started his life with these people and received his first education with them. From his infancy until his marriage, he stayed with them and continued his life under their supervision. Therefore, the foundations of Prophet Muhammad's superior morality were formed by these people. Allahu Ta'ala has given him the supreme morality through these people. The article attempts to reveal the moral and humanitarian characteristics of his relatives, who contributed significantly to the upbringing of the Prophet. Thus, contribution will be made to understanding the foundations on which Prophet Muhammad's morality is nourished.
\end{abstract}

Keywords: Sirah, Amina, Umm Ayman, Abdulmuttalib, Abu Talib. 
75 Mehmet Eser - Adnan Adıgüzel / Hz. Muhammed'in Yetişmesinde Etkili Olan Bazı Kişiler / Some People Who Were Active in The Prophet Muhammad's Upbringing

\section{GİRIŞ}

Hz. Muhammed (as), Arabistan’ın Hicaz bölgesindeki Mekke' de doğmuştur. Bilindiği gibi o daha doğmadan babasını, küçük yaştayken de annesini kaybetmiştir. Onun bebeklikten başlayıp gençlik çağına kadarki dönemde yetişmesinde etkili olan bazı kişiler vardır. Bu çalışmada başta kendi öz annesi Hz. Âmine olmak üzere, sütannesi Hz. Halime, annesinden kendisine miras kalan ve her zaman yanında olan hanım Ümmü Eymen, dedesi Abdülmuttalib, amcası Ebû Talib ile Ebû Talib'in eşi Fatıma bt. Esed hakkında bilgiler verilecektir. Bu kişilerin herbiri Hz. Muhammed'in yetişmesinde önemli bir yere sahip olmuşlardır.

İnsanlar yetişme ve büyüme aşamasında çevresindeki insanlardan etkilenir, kendilerinin yetişmesine katkı sağlayan, sevgisini kazanan ve büyük bir iyilik gördüğü insanları örnek kişiler olarak kabul ederler. Biz de buradan yola çıkarak Peygamberimizin (as) bebekliğinden gençlik çağına kadar etrafında bulunan kişileri ele almak istedik. Bu kimselerin bazı temel özelliklerini ve Hz. Muhammed'e olan yakınlıklarını ve ona desteklerini, aralarındaki insanî bağları tespite çalıştık. Bu kimselerin özellikle de ahlaki özelliklerini ortaya koymaya gayret ettik. Bu ahlaki özelliklerin $\mathrm{Hz}$. Muhammed'in örnek ahlakındaki yerini görmeye çalıştık.

Peygamberimizin İslamiyet öncesi hayatıyla ilgili bilgiler oldukça sınırlıdır. Burada öncelikli kaynağımız Kur'an' daki konuyla ilgili ayetlerdir. Buna ilaveten, önemli siyer kaynaklarından olan İbn İshâk, İbn Hişâm, İbn Hibbân, İbn Sa'd ve Belâzurî gibi müelliflerin eserlerinden istifade edilmeye çalışılmıştır. Bu kaynaklarla birlikte Peygamberimizin hayatıyla ilgili İslam Tarihi alanında telif edilen bazı eserlerdeki anlatımlar da gözden geçirilmiştir. Ayrıca günümüzde bu konuda yapılan çalışmalar incelenerek en doğru bilgi ve yorumlara ulaşılmaya çalışılmıştır.

\section{PEYGAMBERIMIZİN IÇIINDE DOĞDUĞU VE YAŞADIĞI ORTAM}

Peygamberimizin çocukluğunun geçtiği yer, günümüzde Şibhü Cezîreti'l-Arab (Ceziretü'l-Arab) diye adlandırılan bölgede yer almaktadır. Peygamberimiz buradaki önemli yerleşim merkezlerinden Hicaz Bölgesi'ndeki ${ }^{1}$ Mekke' de doğmuştur. O (as), dört yaşına kadar sütannesiyle Taif yakınlarındaki Sa'doğullarının yurdunda kalmıştır. Ardından Mekke'ye getirilerek annesine teslim edilmiştir. Altı yaşındayken annesiyle birlikte babasının kabrinin de bulunduğu Medine'ye gitmiş ve bir müddet burada bulunmuştur. ${ }^{2}$

Peygamberimizin (as) yaşadığı Hicaz'daki başlıca şehirler; Mekke, Medine ve Taif'tir. Bölgenin en önemli yerleşim merkezi olan Mekke dağlarla çevrili bir vadide kurulmuştur. Mekke'yi çevreleyen dağlar arasında Harem'e kadar uzanan şi'b denilen vadiler ve vadilerin birleşim yerlerindeki dar alanlarda meskûn mahalleler bulunmaktadır. Mekke, 330 metre rakımlı,

1 Hicaz Bölgesi; Sahil ovaları (Tihâmetu'l-Hicaz), yüksek sahil kesimleri (Medyen, Ziba) ve yüksek iç bölgelerinden Hımd, Akîk ve Sebâ vadileri, Serhan, Hicaz Platosu, Uveyrid, Rehâ Hayber, Fedek, Leylâ, Kermâ, Kuşeb, Vibre Tepeleri gibi mekânlardan oluşmaktadır. Bk. Sami b. Abdullah Mâğlus, Siyer Atlası, çev. Abdullah Karakaş (İstanbul: Siyer Yay., 2014), 35-42.

2 Muhamed b. İshâk b. Yesâr, Sîretu İbn İshâk, thk. Muhammed Hamidullah (Konya: Hayra Hizmet Vakfı Yay., 1981), 25 vd.; Ebû Muhammed Abdulmelik b. Hişâm, es-Sîretu'n-nebeviye, thk. Mustafa es-Sekâ vd. (Beyrut: Dâru'l-Kütübi'l-İlmiyye, 1971), 128-134. 
Kızıldeniz' in 100 km. kadar doğusunda yer almaktadır. Şehrin kurulduğu vadiye İbrahim Vadisi de denilmiştir. Mekke'nin dağlarla çevrili, adeta çukurda kalan kısmına batnu bitâh denilmiştir. ${ }^{3}$

Mekke şehrine, dokunulmaz, saygın, kutsal mekân anlamında Harem adı verilmiştir. Harem sınırları içinde avlanmak, hayvanları öldürmek, ağaç kesmek ve hatta otları koparmak haram kabul edilmiştir. ${ }^{4}$

Mekke kurak ve dağlık bir alanda yer aldığ1 halde, bu şehrin doğusundaki Gazvân Dağ1 eteklerinde bulunan Taif ise oldukça verimli bir bölgedir. Taif'te hububat yanında, nar, incir, şeftali, üzüm gibi çeşitli meyveler de yetiştirilmektedir. ${ }^{5}$ Bu nedenle Taif, "Hicaz'ın bahçesi/bostanı" (sayfiye yeri) durumundadır. İslamiyet öncesinde de Mekkeli bazı zenginlerin Taif'te yazlıkları ve bağları bulunmaktayd1. ${ }^{6}$ Mekkeli Utbe b. Rebîa, kardeşi Şeybe ve Abbas b. Abdilmuttalib Taif'te üzüm bağları bulunan Mekkelilerdendi. Yine Mekke ve Taif şehirleri arasında sıkı bir sosyal ilişki bulunmaktayd1. ${ }^{7}$

Peygamberimizin doğduğu dönemde her toplumda olduğu gibi Arap toplumunda da ahlaki olarak iyi ve kötü davranışlar vardı. Bu durum Kur'an'da ve Peygambermizin hadislerinde genel anlamda "ma'ruf" ve "münker" kelimeleriyle ifade edilmiştir. Arap toplumunda ahlaki anlamdaki iyi ve kötü davranışlar için "fedâilu'l-Arab" ve "mesâlibu'l-Arab" ifadeleri kullanılmıştır. Bu anlamda toplumsal hayatta fazilet olarak cömertlik, yiğitlik, sözünce durma, namus ve onurlarına düşkünlük, misafirperverlik, ahde vefa ve kanaatkârlık gibi davranışlar vardı. Diğer yandan da cehalet, zorbalık, zina, yetim malı yemek, miras konusunda haksızlıklar, kan davaları, kibir, fuhuş vb. gibi mesâlib kabul edilen davranışlar da bulunmaktaydı. Toplumda iyilikler övgüyle karşılansa da kötülükleri tam olarak engelleyecek bir yaptırım yoktu. Bu dönemde içinde Peygamberimizin de yer aldığı, zulme, zorbalıklara, olumsuzluklara maruz kalanlara destek olmak ve haksızlığa uğrayanların haklarını korumak için Hılfu'l-fudûl denilen yapı oluşturulmuştu. ${ }^{8}$ İşte burada Peygamberimizin hayatında ona destek olduğunu ifade ettiğimiz kişiler de genellikle olumsuzlukla anılan kişiler değillerdi. Onlar bu çalışmanın bundan sonraki kısmında ifade etmeye çalışacağımız gibi daha çok iyilikleriyle meşhur olmuş şahıslardı. Peygamberimizin bu güzel insanlar arasında,

${ }^{3}$ Muhammed b. Sa'd b. Menî́ ez-Zührî, Kitâbü't-Tabakâti'l-kebir, thk. Ali Muhammed Ömer (Kahire: Mektebetu'lHancî, 2001), 1/52, 53; Ebu'l-Velid Muhammed el-Ezrakî, Ahbâru Mekke, çev. Y. Vehbi Yavuz (İstanbul: Feyiz Yay., 1974), 10; Yaşar Çelikkol, İslam Öncesi Mekke (Ankara: Ankara Okulu Yay., 2014), 35-40.

${ }^{4}$ Ebû Abdillâh Muhammed b. İsmâil b. İbrahim el-Cu'fî el-Buhârî, Sahîh-i Buhari, thk. Kâsım eş-Şemmâî er-Rifâî (Beyrut: Dâru'1-Kalem, 1407/1987), "Kitâbu'l-İlm", 89 (no: 93).

${ }^{5}$ Cevâd Ali, el-Mufassal fi târîhi'l-Arab kable'l-İslâm (Beyrut: Dâru's-Sâkî, 1422/2001), 7/142, 152; Muhammed Hamidullah, İslâm Peygamberi, çev. Mehmet Yazgan (İstanbul: Beyan Yay., 2014), 785; M. Şemsettin Günaltay, İslam Öncesi Arap Tarihi (Ankara: Ankara Okulu Yay., 2013), 17.

${ }^{6}$ Ahmed b. Yahya b. Câbir el-Belâzûrî, Futûhu'l-buldân, thk. Abdulkadir Muhammed Ali (Beyrut: Dâru'lKütübi'l-İlmiyye, 2014), 41; Cevâd Ali, Mufassal, 7/142, 153; Emine Öztürk, Hz. Muhammed'in Tebliğ Mücadelesinde Tâif Yolculuğu (İzmir: Dokuz Eylül Üniversitesi, Sosyal Bilimler Enstitüsü, Yüksek Lisans Tezi, 2010), 17-18; W. Montgomery Watt, Hz. Muhammed Mekke'de, çev. M. Rami Ayas - Azmi Yüksel (Ankara: Ankara Üniversitesi İlahiyat Fakültesi Yay., 1986), 146 vd.

${ }^{7}$ Mustafa Sabri Küçükaşc1, "Sâkif", Türkiye Diyanet Vakfi İslâm Ansiklopedisi (İstanbul: TDV Yay., 2009), 36/1011; Öztürk, "Hz. Muhammed'in Tebliğ Mücadelesinde Tâif Yolculuğu", 18.

8 Bu konuda daha geniş bilgi için bk. İbrahim Sarıçam, Hz. Muhammed ve Evrensel Mesajı (Ankara: DİB Yay., 2003), 42; Âdem Apak, Kur'an'ın Geliş Ortamında Arap Toplumu (İstanbul: Kuramer Yay., 2017), 123-158; Çelikkol, İslam Öncesi Mekke, 219. 
77 Mehmet Eser - Adnan Adıgüzel / Hz. Muhammed'in Yetişmesinde Etkili Olan Bazı Kişiler / Some People Who Were Active in The Prophet Muhammad's Upbringing

onların gözetiminde yetişmesi ve yaşaması Allah'ın ona bir lütfuydu. Şimdi peygamberimizin yetiştiği ortam ve ona kol kanat gererek yetişmesini sağlayan bazı kişiler hakkında bilgi vermeye çalışalım.

\section{HZ. PEYGAMBERINN YETISSMESINNE DESTEK OLAN BAZI KIŞSILER}

Kaynaklarda Hz. Muhammed'in nesebini Hz. Âdem'e (as) kadar götüren rivayetler vardır. Ancak onun şeceresinin Adnân'a kadar dayandırılan kısmı daha az ihtilaflıdır. Kusay b. Kilâb'a kadar olan kişiler ise Hz. Muhammed' in şeceresinde bulunan ve en iyi bilinen dedeleridir. Kusay'ın Abdümenaf, Abdüddâr, Abdüluzzâ isimli oğulları vardı. Peygamberimizin soy kütüğü, babası Abdullah ve ondan sonra da Abdülmuttalib b. Hâşim b. Abdimenaf şeklindedir. ${ }^{9}$ Peygamberimizin babasının dedesi Haşim, Hazrec'e bağlı Beni Neccar'dan Selma bt. Amr b. Zeyd ${ }^{10}$ ile evlenmişti. Haşim'in bu evliliğinden Abdulmuttalib doğmuştur. Dolayısıyla Hz. Muhammed'in Medine'de yaşayan Hazrec'ten Neccâroğullarıyla akrabalığı vardı.

Hz. Peygamber'in babası olan Abdullah, Mekke'de Kureyş'ten olan soy ve mevkice kıymetli Âmine isimli bir hanımla evlenmişti. ${ }^{11}$ Abdullah da Mekkeli akranları gibi ticaretle uğraşmaktaydı. Babası Abdülmuttalib, ticaret amacıyla onu Filistin'e (Gazze) göndermişti. Ancak Abdullah sefer dönüşünde yolda rahatsızlanınca dayılarının yanında istirahat etmek ve tedavi görmek için Medine'de kalmıştı. Abdullah, hastalığını atlatamayıp Medine'de vefat etmiş ve buraya defnedilmişti. ${ }^{2}$ Babası Abdullah'tan, geriye miras olarak bir miktar mal ile Ümmü Eymen adında bir de cariye kalmıştı. ${ }^{13}$

\subsection{Hz. Muhammed'in (as) Annesi Âmine bt. Vehb}

Hz. Muhammed'in (as) annesi Âmine'nin tam künyesi; Âmine bt. Vehb b. Abdimenaf b. Zühre b. Kilâb'dır. Eşi Abdullah'ın künyesi ise, Abdullah b. Abdilmuttalib b. Haşim b. Abdimenaf b. Kusay b. Kilâb'tır. Peygamberimizin annesi Âmine dördüncü kuşaktan Kilâb’ın torunu iken, babası

9 İbn İshâk, Sîretü İbn İshâk, 1; İbn Hişâm, es-Sîretu'n-nebeviyye, 21; İbn Sa'd, Tabakât, 1/4; Ebû Hâtim Muhammed b. Hibbân, es-Sîretü'n-nebeviyye ve ahbâru'l-hulefâ, thk. Sa'd Kerîm el-Fakâ (İskenderiyye: Dâru İbn Haldun, 2018), 22, 23; Mustafa Fayda, “Hz. Muhammed (sav)”, Türkiye Diyanet Vakfi İslâm Ansiklopedisi (İstanbul: TDV Yay., 2005), 30/412; M. Asım Köksal, İslam Tarihi (İstanbul: Şamil Yayınevi, 1987), 1/36.

10 İbn Hişâm, es-Sîretu'n-nebeviyye, 93, 94; İbn Sa'd, Tabakât, 1/60, 61; Yusuf b. Abdillah b. Muhammed b. Abdilberr, el-İstîâb fì ma'rifeti'l-ashâb, thk. Ali Muhammed el-Becâvî (Beyrut: Dâru'1-Ceyl, 1992), 1/27; İbrahim Sarıçam, "Neccar", Türkiye Diyanet Vakfi İslâm Ansiklopedisi (İstanbul: TDV Yay., 2006), 32/480-481.

11 İbn İshâk, Sîretü İbn İshâk, 23, 24; İbn Hişâm, es-Sîretu'n-nebeviyye, 126-128; Bekir Topaloğlu, "Âmine," Türkiye Diyanet Vakfi İslam Ansiklopedisi (İstanbul: TDV Yay., 1991), 3/63, 64.

12 İbn İshâk, Sîretü İbn İshâk, 22; İbn Hişâm, es-Sîretu'n-nebeviyye, 127, 128; İbn Sa'd, Tabakât, 1/79-80; Ahmed b. Yahyâ b. Câbir el-Belâzurî, Kitâbu Cümel min ensâbi'l-eşrâf, thk. Süheyl Zekkâr vd. (Beyrut: Dâru'1-Fikr, 1996), 1/101; Ebû Cafer b. Muhammed et-Taberi, Tarihu't-Taberî-Tarihu'r-rusul ve'l-mulûk-, thk. Muhammed Ebu'lFadl İbrahim (Kahire: Dâru'1-Maârif, 1969), 2/165; Muhammed b. Muhammed el-Ya'merî, Uyûnu'l-eser fì funûni'l-megâazî ve'ş-şemâil ve's-siyer, thk. Muhammed el-Îd el-Hadrâvî vd. (Beyrut: Dâru b. Kesîr, ty.), 1/78, 79.

13 İbn Sa'd, Tabakât, 1/80; Belâzurî, Ensâbu'l-eşrâf, 1/105; Semseddin Muhammed b. Ahmed b. Osman ez-Zehebî, Tarihü'l-İslam ve vefeyâti'l-meşâhîri ve'l-a'lâm, -es-Sîretu'n-nebeviyye-, thk. Ömer Abdusselam Tedmurî (Beyrut: Dâru'l-Kutubi'l-Arabî, 1991), 2/50; Mevlânâ Şibli en- Numânî, Sîretü'n-Nebî Son Peygamber Hz. Muhammed (İstanbul: Milli Gazete Yay., 2005), 1/125; Köksal, İslam Tarihi, 1/143; Kasım Şulul, “Allah'ın Himayesinde Yetim ve Öksüz Bir Çocuk" Özel Sayı: 5 (2016) (İstanbul: Turkuaz Yay., 2016), 17; Mustafa Ağırman, “Hz. Peygamber'in Anneleri", EKEV Akademi Dergisi 11/32 (Yaz 2007), 105-124. 
Abdullah Kilâb'ın beşinci kuşaktan torunudur. Âmine, Kilâb'a soy olarak kocası Abdullah'tan bir göbek daha yakındır. ${ }^{14}$

Âmine, babası Vehb'in vefatı üzerine erkek kardeşi Vüheyb'in velâyeti altına girmişti. Abdülmuttalib, Vehb'in kızı Âmine'yi oğlu Abdullah ile evlendirmiştir. Hz. Muhammed, Abdullah ile Âmine'nin evliliğinden doğmuş tek çocuktur. O (as), Mekke'de, Safa Tepesi yakınlarında Beni Haşim mahallesinde, 12 Rebiulevvel/20 Nisan Pazartesi 571'de doğmuştur. Doğumunun Fil Y1lı'na15 rastladığ ${ }_{1}$ rivayet edilmektedir.16

Hz. Muhammed (as), sütannesi Halime'ye verilmeden önceki dört aylık süre içeresinde annesi Âmine ile beraber değişik sütanneler tarafından emzirilmiştir. O (as), daha sonra Mekkelilerin adetleri üzere sütanne olarak anlaşma yapılan Halime' ye teslim edilmiştir. ${ }^{17} \mathrm{~Hz}$. Muhammed dört yıl kadar sütannesi Halime' nin yanında kalmıştır. Sürenin sonunda Halime, onu anne ve dedesine teslim etmiştir. ${ }^{18} \mathrm{Bu}$ dönemden sonra Hz. Muhammed, yaklaşık iki yıl annesi Âmine'yle birlikte kalmıştır. Onun annesiyle geçirdiği bu süre hakkındaki bilgiler oldukça sınırlıdır. Bu dönem ile ilgili bilinen konu, Âmine'nin Hz. Muhammed'in dedesi Abdülmuttalib'den izin alarak oğluyla Medine'ye gitmesidir. Bu ziyaret vesilesiyle Hz. Muhammed babasının kabrinin de bulunduğu Medine' yi ve ayrıca büyükannesi yoluyla akrabaları olan Neccaroğullarını tanıma firsatı bulmuştur. Âmine bu yolculukta Ümmü Eymen'i de yanına almıştır. Âmine, çocuğu Muhammed (as) ve Ümmü Eymen ile birlikte Medine'de bir ay kadar misafir olarak kalmış ve daha sonra tekrar Mekke'ye dönmek için buradan ayrılmıştır. ${ }^{19}$

Âmine, kocası Abdullah'ın Neccaroğulları ile olan akrabalığı nedeniyle Medine'de, Abdülmuttalib' in annesinin memleketinde sıcak bir şekilde ağırlandıklarını kabul edebiliriz. Âmine oğlu ile birlikte Medine' de bulunduğu bu dönemde burada vefat eden eşi Abdullah'ın vefat ettiği evi ve defnedildiği yeri de ziyaret etmişlerdi. O, aynı zamanda Hz. Muhammed'i dayıları olan Neccaroğulları ile tanıştırmıştı. ${ }^{20} \mathrm{~Hz}$. Muhammed de bu ziyaret vesilesiyle Medine' de hoşça vakit

14 İbn İshâk, Sîretü İbn İshâk, 19; İbn Hişâm, es-Sîretu'n-nebeviyye, 127; İbn Sa'd, Tabakât, 1/37, 41, 42; Fayda, “Hz. Muhammed (sav)", 30/408; Toplaloğlu, "Âmine," 3/63.

15 İbn İshâk, Sîretü İbn İshâk, 25, 26; İbn Hişâm, es-Sîretu'n-nebeviyye, 128; İbn Sa'd, Tabakât, 1/81; İbn Kayyim elCevziyye, Zâdu'l-meâd fì hedyi hayri'l-ibâd, thk. Şuayb el-Arnaût vd. (Kuveyt: Mektebetu'l-Menâri'l-İslamiyye, 1994), 1/76; İbn Seyyidi'n-Nâs, Uyûnu'l-eser, 80, 81; Muhammed Hüseyin Heykel, Hz. Muhammed'in Hayatı, çev. Vahdettin İnce (İstanbul: Kitabevi Yay., 2011), 85.

${ }^{16}$ Fil Olayı ile ilgili daha geniş bilgi için bk. İbn İshâk, Sîretü İbn İshâk, 38-44; İbn Hişâm, es-Sîretu'n-nebeviyye, 128; Belâzurî, Ensâbu'l-eşrâf, 1/75 vd.; Mustafa Fayda, "Fil Vak'ası", Türkiye Diyanet Vakfi İslam Ansiklopedisi (İstanbul: TDV Yay., 1996), 13/70, 71.

17 İbn İshâk, Sîretü İbn İshâk, 25-28; İbn Hişâm, es-Sîretu'n-nebeviyye, 128-134; İbn Sa'd, Tabakât, 1/87, 88; Muhammed b. Salih ed-Dimaşkî, Peygamber Külliyatı (İstanbul: Ocak Yayıncılık, 2006), 1/323-324.

18 İbn İshâk, Sîretü İbn İshâk, 25-28; İbn Hişâm, es-Sîretu'n-nebeviyye, 133, 134; Heykel, Hz. Muhammed'in Hayatı, 85; Mehmet Azimli, Siyeri Farkl Okumak (Ankara: Ankara Okulu Yay., 2015), 77; Adem Apak, Ana Hatlarryla İslâm Tarihi (1), Hz. Muhammed Dönemi (İstanbul: Ensar Neşriyat, 2014), 123-124.

19 İbn Hişâm, es-Sîretu'n-nebeviyye, 134, 135; İbn Sa'd, Tabakât, 1/95; Köksal, İslam Tarihi, 2/49, 50; Mahmud Es'ad'ın İslam Tarihi adlı eserinde, Abdullah'ın kabrinin bulunduğu Nabiğg' nın evinin Medine'den iki günlük uzaklıkta mesafededir. Bk. Mahmud Es'ad, Tarih-i Din-i İslam, haz. A.L. Kazanc1 - O. Kazancı (İstanbul: Marifet Yay., 1983), 379. Köksal, İslam Tarihi, 2/49, 50.

20 İbn Hişâm, es-Sîretu'n-nebeviyye, 135; İbn Sa'd, Tabakât, 1/95; Belâzurî, Ensâbu'l-eşrâf 1/103, 104; Taberî, Tarihu't-Taberî, 2/165, 166; Köksal, İslam Tarihi, 49; İbn Abdi'l-Berr, el-İstîâb, 1/24; Apak, Ana Hatlariyla İslâm Tarihi (1), 131. 
79 Mehmet Eser - Adnan Adıgüzel / Hz. Muhammed'in Yetişmesinde Etkili Olan Bazı Kişiler / Some People Who Were Active in The Prophet Muhammad's Upbringing

geçirmişti. O (as), buradaki Beni Adiyy b. Neccâr'ın küçük göletinde yüzmeyi de öğrenmiş, Medine'de kaldığı günlerde Neccaroğullarının mahallesindeki çocuklarla oynamıştı. Hz. Muhammed (as), Medine'ye hicretinden sonra zaman zaman arkadaşlarına buradaki çocukluk hatıralarını anlatmıştır. Örneğin bir defasında Üneyse adında bir kızla surlar üzerinde oynadığını, dayılarının çocuklarından bazılarıyla hisarın üstüne konan kuşları uçurduklarını dile getirmiştir. ${ }^{21}$ $\mathrm{Bu}$ ziyaretten yıllar sonra Hz. Muhammed Medine'ye hicret etmiş, Ensar'dan olan dayılarının yanına yerleşmiş22 ve burada vefat etmiştir.

Âmine, Ümmü Eymen ve Hz. Muhammed'le bir müddet kaldığı Medine'den Mekke'ye dönüş yolunda Ebvâ Köyü̈ ${ }^{23}$ yakınlarında rahatsızlanmış ve vefat etmiş (576), ${ }^{24}$ buraya defnedilmiştir. ${ }^{25}$ Âmine'nin vefatı üzerine Ümmü Eymen, Hz. Muhammed ile Âmine' nin devesini de yedeğine alarak bir kervana katılıp beş günlük yolculuktan sonra Mekke'ye dönmüş ve Hz. Muhammed'i dedesi Abdülmuttalib'e teslim etmiştir. ${ }^{26}$

Âmine' nin oğlu Hz. Muhammed ile olan beraberliği hakkındaki bilgilerimiz ancak çocuğunu dünyaya getirmesi, onunla çıtı̆̆g Medine yolculuğu, Medine'de geçen günler, Mekke'ye dönüş için yola çıkışları ve yolda vefat etmesi ile ilgili rivayetlerle sınırlıdır. Bu rivayetlerden anlaşıldığına göre Âmine oğlu ile yaklaşık iki yıl kadar bir süre beraber olabilmiştir. Amine, kocasının ölümünden itibaren genç bir hanım olarak yaşadığı bu kısa hayatında sabır, metanet, kanaat, sevgi ve vefa örneği bir hanım olduğunu göstermiştir.

\subsection{Sütannesi Hz. Halime}

Peygamberimizin sütannesi Halime, Benî Sa'd kabilesine mensup bir hanımdı. Bu kabilenin yaşadığı yer; yüksek rakımlı, havası serin, suları tatlı, Taif'e yakın bir yaylaydı. Bu özelliklerinden dolayı da çocukların sağlıklı bir şekilde yetişmeleri için çevre kabileler tarafından tercih edilmekteydi. Bu kabileden sütannelik yapan hanımlar, bebekleri belli bir yaşa kadar büyütmeleri karşılığında çocukların ailelerinden bir miktar ücret alırlardı. Çocuklar, sütanne yanında aynı zamanda fasih Arapça da öğreniyorlardı. ${ }^{27}$ Sütanne adayları kendileri için uygun çocuklar bulmak

21 İbn Sa'd, Tabakât, 1/95; Köksal, İslam Tarihi, 2/49, 50; Şulul, “Allah'ın Himayesinde Yetim ve Öksüz Bir Çocuk", 21.

22 İbn Sa'd, Tabakât, 1/210.

${ }^{23}$ Ebvâ: Mekke-Medine yolu üzerinde Medine' ye yaklaşık 190 km. uzaklıktadır. Bugün Râbiğ kasabasına bağlı bir köy olan Ebvâ halâ varlığını sürdürmektedir. Bk. Mustafa Fayda, "Ebvâ", Türkiye Diyanet Vakfı İslam Ansiklopedisi (İstanbul: TDV Yay., 1994), 10/378-379; Mâğlus, Siyer Atlası, 31; Sarıçam, Hz. Muhammed ve Evrensel Mesajl, 64.

24 Bekir Topaloğlu, “Âmine," 63-64; Şulul, “Allah'ın Himayesinde Yetim ve Öksüz Bir Çocuk”, 21; Apak, Ana Hatlarıyla İslâm Tarihi (1), 131.

25 İbn Hişâm, es-Sîretu'n-nebeviyye, 135; İbn Sa'd, 1/104, 105. Bu konudaki farklı rivayetler için bk. Gülgün Uyar, Hz. Muhammed'in Risalet Öncesi Hayatına Dair Bazı Rivayet Farklarının Tespiti (İstanbul: Marmara Üniversitesi, Sosyal Bilimler Enstitüsü, Yüksek Lisans Tezi, 1993), 46; Köksal, İslam Tarihi, 2/53.

26 İbn Sa'd, Tabakât, 1/95; Zehebî, Târîhu'l-İslam -es-Sîretu'n-nebeviyye-, 2/50, 51; İbn Seyyidi'n-Nâs, Uyûnu'l-eser, 99; Apak, Ana Hatlariyla İslam Tarihi (1), 131.

27 İbn Hişâm, es-Sîretu'n-nebeviyye, 134; İbn Sa'd, Tabakât, 1/93; Fayda, “Hz. Muhammed”, 30/409. 
amacıyla Ukâz Panayırı'nın ${ }^{28}$ kurulduğu dönemlerde Mekke'ye gelirler ve burada bebeklerin aileleriyle görüşerek anlaşmalar yaparlard1..29

Sa'doğulları, kökleri Peygamberimizin de atalarından olan Adnân'a dayanmaktaydı. Hevâzin' in Kays Aylan kollarından olan bir kabileydi. ${ }^{30}$ Bu kabile, aynı zamanda şerefi, cömertliği, mertliği ve tevazuu ile bilinmekteydi. Sütannelik ücreti fazla olsa da Mekke'nin ileri gelenleri diğer kabilelerden olan sütanneler yerine Benî Sa'dlı sütanneleri tercih ediyorlardı. ${ }^{31}$ Sa'doğulları, aynı zamanda Arapçayı konuşma konusundaki fesahatiyle de ön plana çıkan kabilelerdendi. Peygamberimiz bir konuşmasında fesahatinin güzelliğini Kureyşli biri olmak yanında bebekliğinde Benî Sa'd içinde geçirdiği yıllara bağlamıştır. ${ }^{32}$

Peygamberimiz dört aylık bir bebekken Halime ve ailesine teslim edilmişti. Halime'nin Abdullah, Enise (Üneyse), Huzafe (Şeyma) adında başka çocukları da vardı. ${ }^{33}$ Sonuç olarak Peygamberimiz yaklaşık dörtyıl burada Halime'nin çocuklarıyla birlikte yaşamıştır. Ayrıca Hz. Muhammed'in çocukken kendisiyle ilginen kardeşinin Şeyma olduğu rivayet edilmiştir. ${ }^{34}$

Rivayete göre Hz. Muhammed'in dedesi Abdülmuttalib kendisine sütanne olarak tutacağ1 Halime'yle konuşmuş, onun adını ve kabilesini sormuştu. Halime'nin, "Adım Halime, Sa'd kabilesindenim." diye cevap vermesi üzerine de onun adı ve kabilesinden yola çıkarak;

“Ne güzel, ne hoş, Sa'd ve Hilm. Bunlar iki güzel haslettir. Dünyanın şerefi ve ahiretin izzeti bunlarla elde edilebilir." 35

demişti. Abdülmuttalib daha sonra Halime' ye kendisine teslim edecekleri çocuğun yetim olduğunu ve ona bakması karşılığında diğer ailelerin verecekleri ücretten daha az ücret verebileceklerini ifade

${ }^{28}$ Ukâz Panayırı, her yıl Zilkade ayının ilk günü başlar ve yirmi bir gün sürerdi. Mekke ile Taif Şehri arasında Taif'e daha yakın bir bölgede kurulurdu. Bk. Mağlus, Siyer Atlası, 86; Çelikkol, İslam Öncesi Mekke, 62-63.

29 İbn İshâk, Sîretü İbn İshâk, 26; İbn Hişâm, es-Sîretu'n-nebeviyye, 130, 131; Seyyid Ebü'1-Âlâ el-Mevdûdî, Tarih Boyunca Tevhid Mücadelesi ve Hz. Peygamber, çev. Ahmet Asrar (İstanbul: Pınar Yay., 1984), 127; Mağlus, Siyer Atlasl, 78.

30 İbn İshâk, Sîretü İbn İshâk, 26; İbn Hişâm, es-Sîretu'n-nebeviyye, 130; İbn Sa'd, Tabakât, 1/90; Çelikkol, İslam Öncesi Mekke, 62-63; İrfan Aycan, "Sa'd b. Bekir", Türkiye Diyanet Vakfi İslâm Ansiklopedisi (İstanbul: TDV Yay., 2008), 35/372; Emine Demil, Hz. Peygamber'in Risâlet Öncesi Hayatına Dair Rivayetler (Ankara: Ankara Üniversitesi Sosyal Bilimler Enstitüsü, Doktora Tezi, 2016), 148; Mustafa Seyyid Keylanî, Hz. Muhammed Hayatı ve Ahlakı (İstanbul: Kitap Dünyası Yayınevi, 2015), 16; Asri Çubukçu, "Halime", 15/338; Ahmet Önkal, "Kays Aylan", Türkiye Diyanet Vakfi İslâm Ansiklopedisi (İstanbul: TDV Yay., 2002), 25/91-92.

${ }^{31}$ Asri Çubukçu, "Hâlime", Türkiye Diyanet Vakfi İslâm Ansiklopedisi (İstanbul: TDV Yay., 1997), 15/338; Fayda, "Hz. Muhammed (sav)", 30/479-481.

32 İbn Hişâm, es-Sîretu'n-nebeviyye, 134; İbn Sa'd, Tabakât, 1/93; Heykel, Hz. Muhammed'in Hayatı 84; Azimli, Siyeri Farklı Okumak, 77; Çubukçu, "Halime", 15/338; Apak, Ana Hatlarıla İslâm Tarihi (1), 123; Fayda, "Hz. Muhammed", 30/409.

33 İbn Hişâm, es-Sîretu'n-nebeviyye, 130; İ̉n Hibbân, es-Sîretu'n-nebeviyye, 31; Fayda, "Muhammed", 30/409; Hatice Nur Ertürk, "Hz. Peygamberin (s) Sütanneleri ve Sütanneye Verilmesi", Siyer Araştırmaları Dergisi 4 (Temmuz-Aralık 2018), 73.

34 İbn Kayyim el-Cevziyye, Zâdu'l-meâd, 1/83; Mehmet Emre, Büyük İslam Kadınları (İstanbul: Vatan Kitapçllı, 1982), 127; Dimaşkî, Peygamber Külliyatı, 1/326.

${ }^{35}$ Ali b. Burhaneddin Halebî, İnsanu'l-uyûn fì sîreti'l-emîn ve'l-me'mûn el-ma'rifetu bi's-sîreti'l-Halebiyye (Misır: Matbaatu'l-Ezheriyye, 1932), 1/106; Ertürk, “Hz. Peygamberin (s) Sütanneleri ve Sütanneye Verilmesi", 73. 
81 Mehmet Eser - Adnan Adıgüzel / Hz. Muhammed'in Yetişmesinde Etkili Olan Bazı Kişiler / Some People Who Were Active in The Prophet Muhammad's Upbringing

etmiştir. Halime bu konuyu eşi Haris'le istişare ettikten sonra Hz. Muhammed'in sütanneliğini kabul etmiştir. ${ }^{36}$

Hz. Muhammed (as), Halime'nin itinayla bakımı sayesinde oldukça gürbüz bir çocuk olmuştur. Halime, iki yıllık sütanneliği sonrasında daha önce yapılan anlaşma gereğince çocuğu annesine teslim etmek üzere Mekke'ye getirmiş, ${ }^{37}$ ancak annesi Âmine'den çocuğun bir süre daha kendi yanlarında kalmasını istemiştir. Âmine de bu dönemde Mekke'deki salgın hastalıktan (taun) çocuğun zarar görebileceği konusundaki endişesinden dolayı onun teklifini kabul etmiştir. Hz. Muhammed sütannesi Halime'yle birlikte tekrar Beni Sa'd yurduna dönmüş, 38 Halime böylece kendi çocuklarıyla birlikte sütannesi olduğu Hz. Muhammed'e toplamda dört yıl kadar bakmıştır. ${ }^{39}$ Halime onu diğer çocuğu Abdullah ile birlikte büyümüştü. ${ }^{40}$ Peygamberimizin kendisinden biraz daha büyük olduğu anlaşılan sütkardeşi Şeyma, zaman zaman onu kucağında taşımış, onu da yanına alarak hayvanlarını otlatmış, ${ }^{41}$ bir anlamda Hz. Muhammed'e ablalık yapmıştır. ${ }^{42}$

Peygamberimiz hayatının farklı zamanlarında ve özellikle de Huneyn Gazvesi sonrasındaki dönemde eline esir düşen sütkardeşi Şeyma'ya ve sütannesi Halime'nin kabilesine mensup kişilere karşı ilgi ve ikramıla onlara vefasını en güzel şekilde göstermiştir. ${ }^{33}$ Böylece o, zor günlerinde Halime ve diğer yakınlarının sıkıntılarını gidermiştir. Peygamberimiz sütannesi ile karşılaştığında ona büyük bir ihtiram göstermiş, ayağa kalkıp "Annem, anneciğim" diye hitap ederek oturması için ridasını altına sermiştir. Bunun yanında onu sonuna kadar dinleyerek sıkıntılarını gidermeye çalışmış, ona ve akrabalarına cömertçe hediyeler vererek uğurlamıştır. ${ }^{44}$

Halime adı gibi hilm sahibi, istişare ehli, ailesine ve evine bağlı, emaneti korumaya önem veren, komşularıyla iyi geçinen bir hanımdı. Onun diğer sütannelerin almadığı, diğerlerine göre daha az ücret verilecek olan yetim bir çocuğu almayı kabul etmesi de kanaatkârlık ve merhametinin bir göstergesi olarak kabul edilebilir. Böylece Hz. Muhammed, bebeklik ve ilk çocukluk döneminde, yumuşak huylu, hilm sahibi ve insanlarla iyi geçindiğini düşündüğümüz Halime ve ailesi yanında kalmış ve ilk eğitimini böyle bir aile içinde yaşayarak almıştır.

\subsection{Hz. Muhammed'in Dedesi Abdülmuttalib ile Beraberliği}

36 İbn İshâk, Sîretü İbn İshâk, 26, 27; İbn Hişâm, es-Sîretu'n-nebeviyye, 130, 131; İbn Sa'd, Tabakât, 1/90, 126; Muhammed Hüseyin Heykel, Halime'nin emzirecek çocuk bulamamasını, Halime'nin bedenen zayıf olması nedeni ile bebek annelerinin Halime'ye bebeklerini vermediklerini belirtir. Bk. Heykel, Hz. Muhammed'in Hayatı, 85; Emre, Büyük İslam Kadınları, 218-214.

37 İbn İshâk, Sîretü İbn İshâk, 27; İbn Hişâm, es-Sîretu'n-nebeviyye, 130; Hamidullah, İslam Peygamberi, 1/44; Köksal, İslam Tarihi, 2/33, 34 .

38 İbn İshâk, Sîretü İbn İshâk, 27; İbn Hişâm, es-Sîretu'n-nebeviyye, 132; İbn Sa'd, Tabakât, 1/91; İbn Hişâm, esSîretu'n-nebeviyye, 1/222; Mevdûdî, Tarih Boyunca Tevhid Mücadelesi, 2/1187.

${ }^{39}$ Heykel, Hz. Muhammed'in Hayatı, 87; Apak, Ana Hatlarıyla İslâm Tarihi (1), Hz. Muhammed Dönemi, 131.

40 İbn Sa'd, Tabakât, 1/90; İbn Hibbân, es-Sîretu'n-nebeviyye,31; Belâzurî, Ensâbu'l-eşrâf 1/102; İbn Seyyidi'n-Nâs, Uyûnu'l-eser, 96.

${ }^{41}$ Levent Öztürk, "Süveybe", Türkiye Diyanet Vakfi İslâm Ansiklopedisi (İstanbul: TDV Yay., 2010), 39/98-99.

${ }^{2}$ İbn İshâk, Sîretü İbn İshâk, 25; İbn Sa'd, Tabakât, 1/90; İbn Kayyim el-Cevziyye, Zâdu'l-meâd, 1/83.

43 İbn Sa'd, Tabakât, 1/93, 94; Muhammed b. Ömer b. Vâkid, Kitâbü'l-Meğâzî̀, thk. Muhammed Abdulkadir Ahmed Atâ (Beyrut: Dâru'l-Kütübi'l-i̇lmiyye, 2013), 2/322, 323; Belâzurî, Ensâbu'l-eşrâf, 1/103-105, 468; Taberi, Tarihu't-Taberî, 3/81; Hamidullah, İslâm Peygamberi, 51.

${ }^{44}$ İbn Hişâm, es-Sîretu'n-nebeviyye, 774, 775; Dimaşkî, Peygamber Külliyatı, 1/326, 327; Numânî, Sîretü'n-Nebî Son Peygamber Hz. Muhammed, 1/127, 333-336. 
Hz. Muhammed, annesi kendisine hamileyken babası Abdullah vefat etmişti. ${ }^{45}$ Dedesi ona sahip çıkmış ve onunla yakından ilgilenmiş ve doğumunun yedinci gününde torununu sünnet ettirmiş ve sünnet yemeği vermişti. Abdülmuttalib, Hz. Muhammed'in doğumu nedeniyle Kâbe'de, şükür duası yapmıştı. ${ }^{46}$

Hz. Muhammed (as), altı yaşındayken de annesi ile gittiği Medine'den dönüşte Ebva'da annesinin vefatıyla öksüz kalmıştı. ${ }^{47}$ Dadısı Ümmü Eymen onu Mekke'ye getirmiş ve dedesi Abdülmuttalib'e teslim etmişti. Abdülmuttalib çocukları içinde oğlu Abdullah'ı çok seviyordu. Oğlu Abdullah'ı kurban edilmekten kurtarmak için 100 deve kurban etmişti. ${ }^{48}$ Abdullah'ın vefatı ile tüm sevgisini onun oğlu olan torunu Hz. Muhammed'e (as) vermişti.

Abdülmuttalib'in, belki de hac ve Kâbe hizmetleriyle kabile başkanlığının kendisine yüklediği sorumluluk nedeniyle sert ve otoriter bir yapıya sahip olduğunu düşnebiliriz. Çünkü o kabilenin reisi ve Mekke' nin en önemli şahsiyetlerinin başında gelmekteydi. Onun ölümü üzerine Mekke halkı matem tutmuş, dükkânlar günlerce açılmamış, onun hakkında mersiyeler söylenmişti. ${ }^{49}$ Abdülmuttalib yaşadığı sürece üstün karakterli, inançlı, iyi kalpli, bir insan, âdil bir lider olarak yaşamıştı. Yine Kâbe' yi yıkmaya gelen Ebrehe ile müzakerede bulunmuştu. ${ }^{50}$ İşte Mekke'nin en önemli şahsiyetlerinden olan dedesinin herkesin oturamadığı minderine Peygamberimizin oturabilmesi, dedesinin bundan büyük bir memnuniyet duyması ve onun sırtını sıvazlamasını ifade eden rivayetler ${ }^{51}$ aralarındaki sıcak dede torun ilişkisinin önemli bir göstergesidir.

Abdülmuttalib torunu üzerinde titrer ve ona daima büyük bir şefkatle bakardı. Yine Abdülmuttalib'i uyandırmak için odasına sadece torunu Hz. Muhammed girebiliyordu. ${ }^{52}$ Dedesi, Hz. Muhammed'in her türlü ihtiyacıyla yakından ilgilenir, onu gözü önünden ayırmazdı. Abdulmuttalib yanında torunu Hz. Muhammed çok ayrıcalıklı bir yere sahipti. Bu durumun Abdulmuttalib'in yetim ve öksüz torununa karşı son derece sevgi dolu yaklaşımı ve bu sevgisini göstermekten çekinmemesinden kaynaklandığını söyleyebiliriz. Sonuçta Abdülmuttalib, 82 yaşında vefatına kadar torununa büyük bir sevgi ve itinayla sahip çıkmıştır. Ümmü Eymen'in anlattığına göre Hz. Muhammed de dedesinin vefatına çok üzülmüş ve arkasından ağlamıştır. ${ }^{53} \mathrm{O}$, torunu Hz. Muhammed'e karşı son derece şefkat ve sevgiyle doluydu ve onun için elinden geldiği kadar en iyi dedelik yapmıştı. ${ }^{54}$ Abdulmuttalib' in toplumsal hayatta ailesine sahip çıkan, iyi bir yönetici ve sevgi, şefkat ve merhemetini torununa en iyi şekilde gösteren bir dede olduğu anlaşılmaktadır.

\footnotetext{
45 İbn İshâk, Sîretü İbn İshâk, 22; Dimaşkî, Peygamber Külliyatı, 1/276; Hamidullah, İslam Peygamberi, 49.

46 İbn İshâk, Sîretü İbn İshâk, 22; İbn Hişâm, es-Sîretu'n-nebeviyye, 129; İbn Kayyim el-Cevziyye, Zâdu'l-meâd, 1/76.

47 İbn Hişâm, es-Sîretu'n-nebeviyye, 134, 135.

48 İbn İshâk, Sîretü İbn İshâk, 10-18; İbn Hişâm, es-Sîretu'n-nebeviyye, 134-126; H. Ahmet Sezikli, "Abdulmuttalib", Türkiye Diyanet Vakfi İslâm Ansiklopedisi (İstanbul: TDV Yay., 1988), 1/272, 273.

${ }^{49}$ Belâzurî, Ensâbu'l-eşrâf, 1/81-85, 95; Sezikli, "Abdulmuttalib", 1/273.

50 Sezikli. “Abdulmuttalib", 1/273.

51 İbn Hişâm, es-Sîretu'n-nebeviyye, 135; İbn Sa'd, Tabakât, 1/96; Ebû Bekr Muhammed b. Müslim b. Ubeydillâh İbn Şihâb ez-Zührî, el-Meğâzzî, çev. Mehmet Nur Akdoğan (Ankara: Ankara Okulu Yay., 2016), 30; İbn Seyyidi'n-Nâs, Uyûnu'l-eser, 99.

52 İbn Sa'd, Tabakât, 1/97; Köksal, İslam Tarihi, 2/57; Es'ad, Tarih-i Din-i İslam, 380.

53 İbn İshâk, Sîretü İbn İshâk, 47; İbn Hişâm, es-Sîretu'n-nebeviyye, 135, 143; İbn Sa'd, Tabakât, 1/97; Belâzurî, Ensâbu'l-eşrâf, 1/92; Zehebî, Tarihü'l-İslam -es-Sîretu'n-nebeviyye-, 2/53, 54.

54 İbn Hibbân, es-Sîretu'n-nebeviyye, 31; İbn Seyyidi'n-Nâs, Uŷ̂nu'l-eser, 99.
} 
83 Mehmet Eser - Adnan Adıgüzel / Hz. Muhammed'in Yetişmesinde Etkili Olan Bazı Kişiler / Some People Who Were Active in The Prophet Muhammad's Upbringing

\subsection{Hz. Muhammed'in (as) Amcası Ebû Talib ve Yengesi Fatıma}

Abdülmuttalib'in vefatından sonra Hz. Muhammed'in sorumluluğunu amcası Ebû Talib'in (ö. 619) üstlenmesi konusunda farklı rivayetler bulunmaktadır. Bunlardan biri, Abdülmuttalib'in doğrudan Hz. Muhammed'i Ebû Talib'e emanet etmesi, kendisinden sonra torununun bakımı için onu görevlendirmesi şeklindedir. ${ }^{55}$ Başka bir rivayete göre, bu konuda kardeşler arasında çekilen kurra neticesinde Hz. Muhammed'e bakma sorumluluğu Ebû Talib-Fatıma bt. Esed ailesine verilmiştir. Diğer bir rivayete göre ise Hz. Muhammed'in (sav) bizzat kendisi amcası Ebû Talib'in yanında kalmak istediğini bildirmiştir. ${ }^{6}$ Bu farklı rivayetler içinde bize göre tercihe şayan olanı, ilk rivayette ifade edildiği gibi Abdulmuttalib' in torununu kendisinden sonra en iyi bakılacağı ve sahip çıkılacağını düşündüğü Ebû Talib ailesine emanet ettiği rivayetidir.

Abdülmuttalib'in vefatı, Hz. Muhammed'in hayatında yeni bir ayrılışı, kopuşu ifade etmişti. Babası ve annesinden sonra şimdi de dedesini kaybetmişti. Bu durum daha sekiz yaşındaki bir çocuk için gerçekten ă̆ır bir manevî zorluk anlamına gelmekteydi. O böyle bir dönemde amcasının yanında kendisi için sıcak bir yuva buldu. Burada amcası ve eşi sorumluluk sahibi kişiler olarak ona kendi çocuklarından bile daha çok özen göstermişler, ona kol kanat germişlerdi. ${ }^{57}$ Ebû Talib yetim olan yeğenine en iyi şekilde sahip çıkmıştı. Onu bir emanet olarak kabul etmiş, merhamet ve sevgisiyle korumaya çalışmıştı. ${ }^{58}$ Babası Abdülmuttalib de Hz. Muhammed'i belki bu yönünden dolayı ona emanet etmişti. Ebû Talib, yeğeni Hz. Muhammed'e evleninceye kadar bakmış, onu çocuklarından ayırmamış, her yönüyle ona babalık yapmaya çalışmıştı. Aralarındaki sıcak bağ, sevgi ve saygı hep devam etmiş; Ebû Talib, risalet döneminde İslamiyet'i kabul etmese de yeğenini hiçbir zaman yalnız bırakmamıştı. ${ }^{59}$

Hz. Muhammed'in bu aile içinde kalması ve en iyi şekilde bakılmasında en önemli paya sahip olanlardan bir diğer kişi de amcasının eşi Fatıma' dır. Yengesi Fatıma'nın künyesi Fatıma bt. Esed b. Hâşim b. Abdimenaf b. Kusay'dır. ${ }^{60}$ Ebû Talib ve Fatıma bt. Esed'in soyları büyük babaları Haşim' de birleşmektedir. Fatıma Hz. Muhammed'in risalet günlerini görmüş, Müslüman olmuş ve Medine'de vefat etmiştir (ö. 4/625).61 Fatıma bt. Esed, çocuklarından dolayı Ümmü Talib ve Ümmü'l-Benin

55 İbn İshâk, Sîretü İbn İshâk, 47; İbn Hişâm, es-Sîretu'n-nebeviyye, 143; Belâzurî, Ensâbu'l-eşrâf 1/92; Taberi, Tarihu't- Taberî, 2/277; İbn Abdi'l-Berr, el-İstîâb, 1/34; İbn Kayyim el-Cevziyye, Zâdu'l-meâd, 1/76.

${ }^{56} \mathrm{~Hz}$. Muhammed de evliliği sonrasında amcası Ebu Talib'in oğlu Hz. Ali'nin bakımını üzerine alarak ona karşı vefa borcunu ödemiştir. Bk. Kenan Ayar, "Hz. Muhammed'in Çocuklarıyla İlişkileri", Dinbilimleri Akademik Araştırma Dergisi 7 /1 (Şubat 2007), 81-124.

57 İbn Abdi'l-Berr, el-İstîâab, 1/37-39; Es'ad, Tarih-i Din-i İslam, 382; Mevdûdî, Tarih Boyunca Tevhid Mücadelesi, 2/1196; Hamidullah, İslâm Peygamberi, 54.

58 İbn İshâk, Sîretü İbn İshâk, 53; İbn Hişâm, es-Sîretu'n-nebeviyye, 143, 144.

59 İbn Hişâm, es-Sîretu'n-nebeviyye, 297, 298; Taberi, Tarih-i Taberî, 3/86; Mevdûdî, Tarih Boyunca Tevhid Mücadelesi, 1/73-74, 2/1196-1197; Abdürrahim Zapsu, Büyük İslam Tarihi (İstanbul: M. Sıralar Matbaas1, 1957), 2/21; Apak, Ana Hatlarryla İslâm Tarihi (1), 189; Köksal, İslam Tarihi, 2/82.

60 İbn Sa'd, Tabakât, 10/211; Mehmet Aykaç, "Fatıma bt. Esed”, Türkiye Diyanet Vakfi İslâm Ansiklopedisi (İstanbul: TDV Yay., 1995), 12/225.

${ }^{61}$ Köksal, İslam Tarihi, 5/13-15; Aykaç, “Fatıma bt. Esed”, 12/225. 
künyeleriyle de anılmıştır. ${ }^{2}$ Fatıma ve Ebû Talib' in, Talib, Âkil, Cafer, Ali isimli oğullarıyla Ümmü Hânî, Cumâne, Rayta ve Esma adında dört de kızları vardı. 63

Ebû Talib Hz. Muhammed'in anne-baba bir amcasıydı. ${ }^{64} \mathrm{O}$, varlıklı bir kişi değildi. ${ }^{65}$ Kâbe ile ilgili görevlerden hacılara su ve yemek ikramında bulunma görevini yürütmekteydi. Bu işleri yürütebilmek için önemli bir malî güce ihtiyaç vardı. O da bu işleri yürütebilmek için elinden geleni yapmaktaydı. Ancak zamanla ekonomik yönden yetersiz kalması dolayısıyla hacılara ikramı devam ettirebilmek için kardeşi Abbas'tan (ra) borç almış, aldığı borçlarını ödeyemeyecek duruma düşünce de, bu borcun karşılığında Arapların büyük bir önem verdiği hacılara yemek ve su ikramı görevini kardeşi Abbas'a devretmek zorunda kalmıştı. Bu görev İslamiyet sonrasında da Abbas ailesinin sorumluluğunda devam etmiştir. ${ }^{66}$

Ebû Talib, fakir düşme pahasına kardeşi Abbas'tan borç alarak bu ikramlarını devam ettirmeye çalışması onun toplumsal hayatta ve kabile içinde önemli ve değerli bir kişi olduğunu göstermektedir. Sekiz yaşından itibaren onun yanında yaşayan Hz. Muhammed, amcasından gördüğü liderlik, özveri ve cömertliği özellikle risaletin Medine döneminde en iyi şekilde yaşatmıştır.

Dedesinin ölümü sonrasında amcası ve yengesi Fatıma bt. Esed Hz. Peygamber'in en büyük destekçisi olmuşlardı. Onlar Peygamberimizi hiçbir zaman kendi öz çocuklarından ayırmamışlar, ellerinden geldiği kadar anne babasının yokluğunu aratmamaya çalışmışlardı. Rivayetlere göre babası Abdülmuttalib gibi o da ailesine Hz. Muhammed gelmeden yemeğe başlamamalarını söylemişti. ${ }^{67}$ Yine dedesi Abdülmuttalib gibi amcası Ebû Talip de Hz. Muhammed'in kendi minderine (makamına) oturmasına kızmak bir yana bundan büyük bir mutluluk duymaktaydı. Ebû Talip Hz. Muhammed'in kendi yerine oturduğunu gördüğü zaman duygularını, "Rebia' nın tannsına yemin ederek söylüyorum, kabile reisliği yeğenime gerçekten yakışıyor." diye ifade etmişti.68

Ebû Talib' in eşi Fatıma, Hz. Muhammed'in temizlik ve bakımıyla da yakından ilgilenmiş, onun saçını taramış, kokular sürmüştür. Evde süt içileceği zaman sütü diğer aile bireylerinden önce Hz. Muhammed'e vermiştir. Yine evdeki yemeğin yetersiz olması durumunda öncelikle Hz. Muhammed'in doyabilmesi için ona ayrı bir tabakta yemek ayırmıştır. ${ }^{69}$

\footnotetext{
${ }^{62}$ Abdülaziz Kutluay, Siyer-u Sahabe Hz. Resulullah'ın Yakınları (Şanlıurfa: İpek Yay., 2005), 68.

63 İbn Sa'd, Tabakât, 1/100, 10/211; Mevdûdî, Tarih Boyunca Tevhid Mücadelesi, 2/1195.

64 İbn İshâk, Sîretü İbn İshâk, 47; İbn Hişâm, es-Sîretu'n-nebeviyye, 143; Mevdûdî, Tarih Boyunca Tevhid Mücadelesi, 1/73-74, 2/1197.

65 İbn Sa'd, Tabakât, 1/107; Belâzurî, Ensâbu'l-eşrâf 1/105, 106; Köksal, İslam Tarihi, 2/79; Heykel, Hz. Muhammed'in Hayatı, 90.

${ }^{6} 6$ İbn İshâk, Sîretü İbn İshâk, 47; İbn Hişâm, es-Sîretu'n-nebeviyye, 142, 143; Ethem Ruhi Fuğlalı, "Ebu Talib", Türkiye Diyanet Vakfi İslâm Ansiklopedisi (İstanbul: TDV Yay., 1994), 10/237-238.

67 İbn Sa'd, Tabakât, 1/97, 98; Şulul, “Allah'ın Himayesinde Yetim ve Öksüz Bir Çocuk," 22.

68 İbn Sa'd, Tabakât, 1/98; Zapsu, Büyük İslam Tarihi, 2/21.

69 İbn Seyyidi'n-Nâs, Uyûnu'l-eser, 103, 104.
} 
85 Mehmet Eser - Adnan Adıgüzel / Hz. Muhammed'in Yetişmesinde Etkili Olan Bazı Kişiler / Some People Who Were Active in The Prophet Muhammad's Upbringing

Hz. Muhammed (as), yengesi Fatıma'nın kendisine yaptığı anneliği hiçbir zaman unutmamış, onu her zaman hayırla yâd etmiştir. Onun kendisi için yaptığ1 fedakârlığ1 yıllar sonra, "O kendi çocuklarını aç bırakıp, beni doyururdu" diyerek ifade etmiştir.70

Arabistan'da halkın geçim kaynaklarından biri hayvancılıktı. Hz. Muhammed de, 10-12 yaşlarında hem kendi hayvanlarına ve hem de ücret karşılığında aileye katkı için amcasının yönlendirmesiyle komşularının hayvanlarına çobanlık yapmıştı. ${ }^{71}$ Aslında o dönem şartlarında bu işi hemen hemen her çocuğun yaptığı işlerden biri olarak kabul edebiliriz. Diğer yandan çobanlık insanlara doğayla baş başa kalma ve tefekkür etme imkânı vermekteydi. Hz. Muhammed de hayatının bir döneminde çobanlık yapmıştı. $\mathrm{O}$, peygamberlik günlerindeki bir konuşmasında da Mekkelilerin koyun-keçilerini belli bir ücret karşılığında güttüğünü dile getirmiştir. Öte yandan o (as), diğer peygamberlerin de kendisi gibi çobanlık yaptığını ifade etmiştir.72

Hz. Muhammed zaman zaman amcası Ebû Talib'le birlikte ticaret kervanlariyla sefere de çıkmıştır. Rivayete göre Hz. Muhammed (as), amcasının yanında kaldığı ilk dönemlerde Ebû Talib' in Mekke' den ticaret için ayrılacağı sırada amcasına sarılmış, ağlayarak kendisini de yanında götürmesini istemiştir.73 Ebû Talib onun ssrarlı yalvarmasına dayanamayarak ticaret kervanyla yeğenini de yanında götürmüştür. Hz. Muhammed böylece daha 9-12 yaşlarında bir çocukken amcası Ebû Talib'le Şam bölgesine giden ticaret kervanına katılmıştı. ${ }^{74} \mathrm{Bu}$ çabalarıyla Hz. Muhammed amcasının yanında, onun desteğiyle hayata tutunmaya çalışmıştır. Amcasıyla birlikte katıldığı ticaret kervanı sayesinde ticarî hayatla ilgili bilgi ve tecrübe kazanmıştır. Hz. Muhammed'in (as) amcasının ticarî hayatta başarılı olmak için gerekli ve önemli olan özelliklerden sabır, tevazu ve karşılıklı anlaşmaların gerçekleşmesi için gerekli olan ikna kabiliyeti ve tecrübesinden yararlanmış olduğunu düşünebiliriz.

Peygamberimiz, on yedi yaşındayken diğer amcası Zübeyr'in ticaret kervanına katılarak Yemen'e gitmiştir. ${ }^{75}$ Daha sonraki dönemde de ticarî faaliyetleri devam etmiş, bu anlamda Hubâşe,

70 İbn Sa'd, Tabakât, 1/98; Nureddin Heysemî, Mecmûatu'z-zevâid ve menbai'l-fevâid, thk. Hüsameddin el-Kudusî (Beyrut: Dâru'1-Kitâbi'l-Arabî, ts.). 9/256; Hamidullah, İslâm Peygamberi, 54.

71 İbn Sa'd, Tabakât, 1/103, 104; Zehebî, Tarihü'l-İslam -es-Sîretu'n-nebeviyye-, 2/54, 55; İbn Seyyidi'n-Nâs, Uyûnu'leser, 112; Numânî, Sîretü'n-Nebî Son Peygamber Hz. Muhammed, 1/129.

72 İbn Hişâm, es-Sîretu'n-nebeviyye, 134; İbn Sa'd, Tabakât, 1/103-104; Zeynep Canan Koçak, “Arap Yarımadası'ndaki Ekonomik Şartların Hz. Peygamber'in (sav) Hayatına ve Hadislere Yansıması", Bartın Üniversitesi İslami İlimler Fakültesi Dergisi 4/8 (Güz 2017), 76; Ali Şeriati, Muhammed Kimdir (Ankara: Fecr Yay., 1988), 19; Numânî, Sîretü'n-Nebî Son Peygamber Hz. Muhammed, 129.

73 Taberi, Tarihu't-Taberî, $2 / 277$.

74 İbn İshâk, Sîretü İbn İshâk, 54; İbn Hişâm, es-Sîretu'n-nebeviyye, 144; İbn Sa'd, Tabakât, 1/99; Taberî, Tarihu'tTaberî, 2/278; Hamidullah, İslâm Peygamberi, 56; Muhammed Hamidullah, "Hz. Peygamber'in İslam Öncesi Seyahatleri", çev. Abdullah Aydınl, Atatürk Üniversitesi İlahiyat Fakültesi Dergisi 4 (Haziran 1980), 327-345; Celâl Yeniçeri, Hz. Muhammed'in Ailesi, Köle-Cariye ve Hizmetçileri (İstanbul: Marmara Üniversitesi İlahiyat Fakültesi Yayınları, 2000).

75 İbn Şihâb ez-Zühri, el-Meğâzi, 30; Casim Avc1, "Peygamberliğinden Önce Hz. Muhammed," İslami İlimler Araştırma Vakfi Yay. (Ekim 2010), 134; Casim Avcı "Peygamberliğinden Önce Hz. Muhammed (sav)", Vahyin Nüzulünün 1400 Yilında Hz. Muhammed 15-17 Ekim 2010 Milletler Arası Toplantı, ed. Ahmet Kavas (İstanbul: İslami İlimler Araştırma Vakfı Yay., 2011.) Ezrakî, Ahbâru Mekke, 178-179; Köksal, M. Asım, İslam Tarihi, 124. 
Cüreş, ${ }^{76}$ Debâ panayırlarına katılmıştır. ${ }^{77} \mathrm{O}$ (as), bu vesileyle farklı bölgelerdeki insanları, onların kültürlerini, yaşam şartlarını, ticaret anlayışlarını, örf-adetlerini, lehçelerini, dinî ve siyasi durumlarını tanıma imkânı bulmuştur.

Hz. Muhammed sonuç olarak amcasının yanında başladığı ticarî işler konusunda elde ettiği tecrübelerle ticaret kervanlarında tek başına sorumluluk alacak duruma gelmiştir. ${ }^{78}$ Onun cahiliye dönemindeki "el-Emin"79 (güvenilir) sıfatını alarak "Muhammedü'l-Emin" şeklinde anılması da muhtemelen ticarî hayattaki dürüstlüğünün bir belgesiydi. Çok genç yaşta, dürüstlüğe önem veren biri olarak "erdemliler topluluğu" diye ifade edebileceğimiz "Hilfü'l-fudûl" grubu içinde yer almıştı. ${ }^{80}$

Ebû Talib ve eşi Fatıma, Hz. Muhammed'in evlenmesine de destek vermişlerdir. ${ }^{81}$ Evlenerek onların yanından ayrılması sonrasında da aralarındaki güçlü aile bağları devam etmiştir. Onlar oğulları Ali'yi çocukluğunda gönül rahatlığı ile Hz. Muhammed'in yanına vermişlerdir. Hz. Muhammed belki de yengesine olan sevgi ve saygısının bir göstergesi olarak kızının adını Fatıma koymuş ve daha sonra da bu kızını bu amcasının oğlu Hz. Ali ile evlendirmiştir. ${ }^{82}$ Böylece kendisine annelik yapan amcasının eşi Fatıma kızı Fatıma'ya kayınvalide olmuştu. ${ }^{83}$

En zor günlerinde hep yanında yer alan ve kendisine destek olan amcası ve eşi Hz. Hatice' nin hicretten üç yıl kadar önce az bir arayla (620) vefat etmesi dolayısı ile o yıl "Hüzün yılı" 84 olarak anılmıştır.

Ebû Talib'in vefatından hemen sonra ve hicretten yaklaşık iki yıl önce Fatıma bt. Esed İslamiyet'i kabul etmiş, daha sonra da Medine'ye hicret eden muhacirlerden olmuştur. Medine' deyken Peygamberimiz onu evinde ziyaret eder ve onun evinde dinlenirdi. ${ }^{85}$ Hicretten sonraki dördüncü yılda Medine' de vefat etmiştir. Hz. Muhammed (as) Hz. Fatıma bt. Esed'in vefatına çok üzülmüş ve onun ölümü üzerine, yetim bir çocuk olarak onun yanında kaldığı dönemde yengesinin kendisine annelik yaptığını ve her türlü ihtiyacını en iyi şekilde karşıladığını belirtmiştir. Hz. Muhammed, onun ölümüne üzüntüsünün bir tezahürü olarak o zamana kadar hiç yapmadığı bir şey yapmış, definden önce bir süre yengesinin defnedileceği kabre kendisi uzanmıştı. Yengesi için kefen olarak da kendi gömleğini vermiş, teçhiz ve tekfini esnasında gözyaşı dökmüştü. Bütün bunların bir

${ }^{76}$ Cahid Kara, "İslâm Öncesi Arap Yarımadasında Bir Kültür Merkezi: Cüreş”, Hitit Üniversitesi Illahiyat Fakültesi Dergisi 14/24 (2015/1), 23-49.

77 Ahmed b. Hanbel, Müsned (y.y.: b.y., ts.), 4/206; Hamidullah, "Hz. Peygamber'in İslam Öncesi Seyahatleri", 327-340; Mustafa Ağırman, "Debâ", Türkiye Diyanet Vakfi İslâm Ansiklopedisi (İstanbul: TDV Yay., 1994), 9/61.

78 İbn İshâk, Sîretü İbn İshâk, 59, 60; İbn Hişâm, es-Sîretu'n-nebeviyye, 149; İbn Sa'd, Tabakât, 1/108; Taberî, Tarihu'tTaberî, 2/180-182; Köksal, İslam Tarihi, 2/140-142.

79 İbn Sa'd, Tabakât, 1/99; Zührî, el-Meğâzi, 31.

${ }^{80}$ Hilfü'l-fudûl; Hz. Muhammed 20 yaşında iken Kureyş iinde "Hilfü'l-fudûl" adıyla anılan bir yapı ortaya çıkmıştı. İbn Sa'd'ın rivayetine göre Hilfü'l-fudûla (erdemliler yemini) katılanlar, mazlum ve hakkı yenen kişilerin haklarını savunmak amacını güdüyorlardı. Bk. İbn Hişâm, es-Sîretu'n-nebeviyye, 111-118; İbn Sa'd, Tabakât, 1/106, 107; Muhammed Hamidullah, "Hilfü'l-Fudûl", Türkiye Diyanet Vakfi İslâm Ansiklopedisi (İstanbul: TDV Yay., 1998), 18/31.

${ }^{81}$ Taberi, Tarih-i Taberî, 2/281; Belâzurî, Ensâbu'l-eşrâf 1/106, 107.

82 İbn İshâk, Sîretü İbn İshâk, 230; İbn Abdi'l-Berr, el-İstîâb, 1/37, 38.

83 İbn Sa'd, Tabakât, 10/211.

84 İbn Sa'd, Tabakât, 1/103; M. Yaşar Kandemir, “Hatice”, Türkiye Diyanet Vakfi İslâm Ansiklopedisi (İstanbul: TDV Yay., 1997), 16/465-466.

85 İbn Sa'd, Tabakât, 10/211, 241; Aykaç, “Fatıma bt. Esed”, 12/225. 
87 Mehmet Eser - Adnan Adıgüzel / Hz. Muhammed'in Yetişmesinde Etkili Olan Bazı Kişiler / Some People Who Were Active in The Prophet Muhammad's Upbringing

sonucu olarak Hz. Muhammed'in kendilerinden en çok iyilik gördüğü kişilerin Ebû Talib ve eşi Fatıma olduğunu olduğu yorumu yapılmıştır. ${ }^{86}$

\subsection{Dadısı Ümmü Eymen (Bereke bt. Sa'lebe b. Amr Habeşiyye)}

Ümmü Eymen (ö. 24/645), Hz. Muhammed'in çocukluğundan itibaren kendisine en çok destek veren kişilerden biridir. O, Habeşistan asıllı bir cariyeydi ve Hz. Muhammed'e (as) babası Abdullah'tan miras kalmıştı. Ümmü Eymen ile Hz. Muhammed'in hayatlarının kesişmesi, doğduğu günlerde başlamıştır. ${ }^{87}$

Ümmü Eymen, Abdullah'in ölümü ve Hz. Muhammed'in sütanneye verilmesiyle, Âmine'nin en yakın dostu ve dert ortağı olmuştur. Hz. Muhammed sütanneden geldikten sonraki dönemde de daima Peygamberimizin yanında bulunmuştur.

Ümmü Eymen, Peygamberimizin vefatına kadar dâr-1 saadetin (Peygamber hanesinin) değişmez bir üyesi olarak kalmıştır. ${ }^{88} \mathrm{O}$, Hz. Muhammed'e hem dadı, hem anne olmuştur. Hz. Muhammed'in bakımını dedesi Abdülmuttalib, Ümmü Eymen'in desteği ve hizmetiyle yürütmüştü. ${ }^{89}$

Hz. Muhammed (as), Hz. Hatice ile evlenince Ümmü Eymen'i90 ve kendisine Hz. Hatice tarafından hediye edilen Zeyd b. Harise' yi $^{91}$ azat etmiş ve bu iki kişinin evlenmesini sağlamıştır. ${ }^{92}$ Ümmü Eymen ile Zeyd b. Harise'nin evliliğinden, Üsame isimli çocukları dünyaya (614) gelmişti. Hz. Muhammed (as), Ümmü Eymen'in eşi olan Zeyd b. Harise'yi de çok severdi. Onun bu sevgisi nedeniyle Zeyd'e "Zeydü'l-Hubb" da denilmekteydi.93 Zeyd, hicretten sonraki dönemde birçok gazve ve seriyyeye katılmış ve defalarca seriyye komutanlığı yapmış, komutan olarak katıldığı Mute Savaşı' nda şehit olmuştur (8/629). ${ }^{94} \mathrm{~Hz}$. Muhammed (as), Zeyd'in oğlu Üsame'nin de insanlar

${ }^{86}$ Heysemî, Mecmûatu'z-zevâid, 9/256; Hamidullah, İslâm Peygamberi, 54; Aykaç, "Fatıma bt. Esed", 12/225; Ağırman, "Hz. Peygamber' in Anneleri," 105-124.

87 İbn Kayyim el-Cevziyye, Zâdu'l-meâd, 1/83; Bünyamin Erul, “Ümmü Eymen”, Türkiye Diyanet Vakfi İslâm Ansiklopedisi (İstanbul: TDV Yay., 2012), 42/317; Hamidullah, İslâm Peygamberi, 51; Seval Alkan, Saadet Asrının Nurdan Anneleri Hanım Sahabeler (İstanbul: Zafer Yay., 2012), 44.

88 İbn Sa'd, Tabakât, 10/212; Mevlânâ Niyaz, Kadın Sahabeler, çev. Ali Genceli (İstanbul: Toker Yay., 1971), 300; Mehmet Akbaş, “Hz. Resulullah Döneminde Evlilik ve Düğün” (İstanbul: Turkuvaz Yay., 2016), 122; Erul, "Ümmü Eymen", 41/317.

89 İbn Sa'd, Tabakât, 1/97; İbn Seyyidi'n-Nâs, Uyûnu'l-eser, 98; Köksal, İslam Tarihi, 1/56-58; Casim Avc1, Muhammedü'l Emin Hz. Muhammed'in Peygamberlik Öncesi Hayatı (İstanbul: Hayy Kitap, 2008), 89.

90 İbn Sa'd, Tabakât, 10/212; Numânî, Sîretü'n-Nebî Son Peygamber Hz. Muhammed, 125; Hamidullah, İslâm Peygamberi, 51; Alkan, Saadet Asrinin Nurdan Anneleri Hanmm Sahabeler, 44.

91 İbn Sa'd, Tabakât, 10/212; Köksal, İslam Tarihi, 3/104; Köksal, İslam Tarihi, 2/161-166; Ayşegül Dadan, Ümmü Eymen Hayatı ve Şahsiyeti (Konya: Selçuk Üniversitesi, Sosyal Bilimler Enstitüsü, Yüksek Lisans Tezi, 2009), 14.

92 İbn Sa'd, Tabakât, 1/428; İbn Sa'd, Tabakât, 10/212; İbn Kayyim el-Cevziyye, Zâdu'l-meâd, 1/83; Niyaz, Kadın Sahabeler, 297; Mehmet Salih Arı, "Üsâme b. Zeyd", Türkiye Diyanet Vakfi İslâm Ansiklopedisi (İstanbul: TDV Yay., 2012), 42/361-363; Dadan, "Ümmü Eymen Hayatı ve Şahsiyeti”, 14.

${ }^{93}$ Dadan, "Ümmü Eymen Hayatı ve Şahsiyeti", 15.

94 İbn Sa'd, Tabakât, 2/119; Bünyamin Erul, "Zeyd b. Hârise”, Türkiye Diyanet Vakfi İslâm Ansiklopedisi (İstanbul: TDV Yayınlar1, 2013), 44/320. 
arasında en çok sevdiği kişi olduğunu ifade etmiştir. ${ }^{95}$ Peygamberimizin onu çok sevdiği için, sahabe tarafından kendisine "sevgili oğlu sevgili" (hibbu'bni'l-hibb/الحب ابن حب) denilmiştir.96

Ümmü Eymen, Hz. Muhammed'in (as) ailesi içinde düşüncelerini, isteklerini rahatllkla söyleyebilen biriydi. Onunla ilgili rivayetlere bakılınca Hz. Muhammed’le yakınlığının vefatına kadar devam ettiğini görmekteyiz. ${ }^{97}$ Ümmü Eymen, onun odasına serbestçe girebilirdi. ${ }^{98} \mathrm{~Hz}$. Muhammed de Ümmü Eymen'i sık sık ziyaret eder, zaman zaman onunla şakalaşırdı. ${ }^{99}$ Ümmü Eymen aynı zamanda Hz. Muhammed'in en zor günlerini yaşadığı Uhud, Hayber ve Huneyn muharebelerinde de bir grup kadınla orduya destek vermişti. ${ }^{100}$ Yine Hz. Aişe'ye iftira olayında da Ümmü Eymen ailesi Hz. Aişe lehine şahitlik yapmıştı. ${ }^{101}$

Hz. Muhammed (sav) Ümmü Eymen'in oğlu Usame'yi torunları Hasan ve Hüseyin'den ayırmamıştı. Üsâme, anne babası gibi Hz. Peygamber'in yakınında büyümüş, onun güvenine ve iltifatına mazhar olmuş sahabeydi. Ümmü Eymen, yurdundan koparılmış köle bir hanım olarak mahzun ve kırık bir gönle sahipti. Özverisi, temizliği, dürüstlüğü, güvenilirliği, ailesine ve sevdiklerine samimi bağlılığı ile ölünceye kadar Hz. Muhammed'ın hep yanında, yakının bulunmuştu.

\section{SONUÇ}

Hz. Muhammed (as), yüce ve ideal ahlakın timsali bir insan olarak yaşamıştır. Allah tarafından bütün insanlığa örnek bir rehber olarak görevlendirilmiştir. Yüce Allah (cc), Hz. Muhammed'in (as) yüce bir ahlaka sahip olduğunu ifade etmiş ve bundan dolayı da Müslümanlara örnek göstermiştir. Onun hayatı peygamberlik öncesi ve sonrasıyla saygıyla yâd edilen bir hayattır. Böyle bir insanın eğitimi ve yetişmesinde ona annelik, babalık yapan kişilerin elbetteki ahlak bakımından önemli bir rolü olmuştur. Peygamberimizin bir konuşmasında fesahatinin güzelliğini Kureyşli biri olmak yanında bebekliğinde Benî Sa'd içinde geçirdiği yıllara bağlaması da eğitiminde çevresinin öneminin bir ifadesidir. Fasih dili yanında diğer ahlaki ve insanî yönlerinin şekillenmesinde de çevresinde kendisine kol kanat geren insanların etkisi ve katkısı olduğunu kabul etmek gerekir.

Allah Teâlâ, Hz. Muhammed'in doğumundan itibaren öncelikle annesi Âmine, sütannesi Halime, Ümmü Eymen, Abdülmuttalib, Ebû Tâlib ve Fatıma bt. Esed'in gözetim ve destekleriyle yetişmesini sağlamıştır. Bu kişilerin her biri onun yetişmesine farklı yönlerden önemli katkılar sağlamışlardır. Âmine kocasının vefatı sonrasında tekrar evlenmemiş, kendisini çocuğuna adayan bir anne olmuştur. Genç yaşta eşini kaybedip dul kalan Âmine'nin yaşadığı hayata bakılınca

\footnotetext{
${ }^{95}$ Buhârî, "Meğâzî", (no: 187)

96 Arı, "Usâme," 42/461, 462.

${ }^{77}$ Buhârî, “Et'ime”, (no: 12); İbn Sa'd, Tabakât, 10/212-215; Dadan, “Ümmü Eymen Hayatı ve Şahsiyeti”, 31-35.

${ }^{98}$ Hamidullah, İslâm Peygamberi, 679; Ağırman, "Hz. Peygamber'in Anneleri", 105-124.

99 İbn Sa'd, Tabakât, 10/213; Yusuf Doğan, “Hz. Peygamber ve Mizah”, Cumhuriyet Üniversitesi İlahiyat Fakültesi Dergisi 8/2 (Aralık 2004), 191-203, Dadan, "Ümmü Eymen Hayatı ve Şahsiyeti”, 32; Mehmed Cemal Ögüut, İslam Tarihinin Maruf Simalarından Hz. Muhammed'in Dadısı Ümmü Eymen (İstanbul: Bürhaneddin Matbaası, 1941), 22-23.

100 İbn Sa'd, Tabakât, 10/214; Vâkıdî, Kitâbü'l-Meğââ̂, 2/149; İbn Abdi'l-Berr, el-İstîâb, 1/128; Zehebî, Tarihü'lİslam -es-Sîretu'n-nebeviyye-, 1/444; Dadan, “Ümmü Eymen Hayatı ve Şahsiyeti”, $28,29$.

101 Vâkıdî, Kitâbü'l-Meğââî, 1/366; İbn Hişâm 3/413.
} 
89 Mehmet Eser - Adnan Adıgüzel / Hz. Muhammed'in Yetişmesinde Etkili Olan Bazı Kişiler / Some People Who Were Active in The Prophet Muhammad's Upbringing

sabrıyla, tevekkülüyle, kanaatkârlığıyla ve hayatın çilelerine rağmen dirayetli bir şekilde ayakta kalmayı başaran iyi bir anne modeli olduğu görülecektir. Âmine'nin bu güzel hasletleri oğlunda hayat bularak yaşamaya devam etmiştir.

Hz. Muhammed'e sütannelik yapan Halime de başkalarının çocuklarını emzirmek ve bundan kazanç elde etmek durumunda olan bir annedir. O, yetim ve ekonomik olarak durumları çok da iyi olmayan bir ailenin çocuğunu almaya razı olmuştur. Halime, bu davranışıyla kanaatkârlığını göstermişti. $\mathrm{O}$, aynı zamanda adıyla uyumlu bir kişiliğe sahip yumuşak huylu, merhametli, istişare ehli, evine bağlı, emaneti muhafaza eden ve çevresiyle uyumlu bir kişiydi. O, Hz. Muhammed'i dört aylıkken aldı ve bu güzel özellikleriyle ona sahip çıktı, onu yetiştirmeye çalıştı. Hz. Muhammed dört yaşını bitirene kadar ona annelik yaptı, baktı, kol kanat gerdi. Dolayısıyla Hz. Muhammed yürümeyi, konuşmayı, oynamayı, paylaşmayı birlikte işler yapmayı ilk önce Halime annenin yanında öğrenmiştir. Peygamberimiz onun yanında çalışma azmi, sabır, hilm, emanete özenle sahip çıkma, istişareyle karar verme gibi özelliklerin somut halini görmüştür.

Hz. Muhammed, annesinin vefatından sonra, altı yaşından sekiz yaşına kadar, kendine güveni tam, otoriter, sözünün eri ve ikna kabiliyeti yüksek olan dedesi Abdulmuttalib' in yanında kalmıştır. Bu iki yılını ondan sonsuz destek ve merhamet görerek yaşamıştır. Onun postuna oturmuş, onunla birlikte büyüklerin toplantılarına katılmış, daha çok küçük yaşlardayken başka çocukların yaşaması pek mümkün olmayan bir konumda bulunmuştur. Dedesinin insanî ve liderlik özelliklerini en iyi şekilde almış ve zamanı gelince de hayata geçirmiştir.

Peygamberimiz dedesinin ölümü sonrasında kabilesinin reisliğini üstlenen amcasının yanında yaşamaya devam ederken aynı ayrıcalıklı durumunu devem ettirmiştir. Sekiz yaşından 25 yaşında evleninceye kadar amcasının evinde en önemli aile üyesi olarak değer görmüştür. Amcası başlangıçta Mekke'ye gelen hacılara ziyafetler veren zengin biri olduğu halde daha sonra bu Kâbe hizmetleriyle ilgili bu işini yürütemeyerek kardeşi Abbas'a devretmiştir. Amcası Ebû Tâlib, varlı̆̆ı ve yokluğu bilen, Allah'ın evinin misafiri olarak kabul edilen hacılara ikram için malını sonuna kadar harcayan, hatta bu ikramlarını devam ettirmek için borç alan biriydi. O, kabile başkanı olarak, insanları idare etmeyi ve insanlarla ilişkisini en iyi şekilde sürdürmeyi başarmıştı. Aynı zamanda ticaret erbabı olarak Yemen' den Suriye' ye uzanan hatta birçok farklı kabile ve milletle iyi ilişkilerini sürdüren bir tüccardı. Onun bütün bu tecrübe ve özellikleri sekiz yaşından itibaren yıllarca beraber yaşadığı ve kendisine çok değer verdiği yeğeni Hz. Muhammed tarafından en iyi şekilde temsil edilmiştir.

Ebû Talib'in eşi Fatıma bt. Esed de Hz. Muhammed'e annelik yapmıştı. Hz. Muhammed'i kendi çocuklarından ayırmamış, hatta onu bir emanet olarak kabul edip kendi çocuklarından bile öncelikli görüp, merhametli, cömert bir sevgi ve sahiplenme ile onu korumaya çalışmıştı.

Son olarak Hz. Muhammed'e annelik yapan bir başka kişi de kölelik geçmişiyle gönlü kırık bir hanım olan Ümmü Eymen'di. O da ahlakı, dostluğu, cesareti, kanaatkârlığı, işini en iyi şekilde yapmasıyla ön plana çıkmıştı. Hz. Muhammed'in bebekliğinden itibaren her zaman onun yanında yer almıştı. $\mathrm{O}$ da ailesiyle birlikte, Hz. Muhammed' in eşini ve çocuklarını kendi ailesinin en değerli ve sevgili üyeleri olarak kabul etttiği bir kişi olmuştu. Yaşadığı hayatta sabır, tevekkül, metanet, sükûnet, yaşadığı ortama ve aileye uyum ve bağlılık gibi birçok güzel özelliğiyle örnek bir insandı. 
İnsan genel anlamda yetiştiği ortamın bir ürünü olmaktadır. Hz. Muhammed'in sahip olduğu yüce ahlakı kazanmasına vesile olduğunu düşündüğümüz bu kişilerin onunla olan birlikteliğinin çok değerli olduğunu kabul ediyoruz. Hz. Muhammed'in insan olarak sahip olduğu yüce ahlaki değerleri Allah'ın bir lütfu olarak doğumundan itibaren önemli ölçüde kendisine annelik-babalık yapan bu kişiler kanalıyla ona aktarıldığını düşünüyoruz. Peygamberimiz (as), bu kişilerden sevgi, merhamet, bağışlama, fedakârlık vb. örnekliği yanında liderlik, insanlarla iyi ilişkiler kurabilme ve sürdürme, karşılaşılan problemleri en güzel şekilde çözebilme vb. gibi konularda en iyi şekilde istifade ederek Allah'ın seçtiği âlemlere rahmet olan bir insan haline gelmişti. 
91 Mehmet Eser - Adnan Adıgüzel / Hz. Muhammed'in Yetişmesinde Etkili Olan Bazı Kişiler / Some People Who Were Active in The Prophet Muhammad's Upbringing

\section{KAYNAKÇA}

Ağırman, Mustafa. "Debâ". Türkiye Diyanet Vakfi İslâm Ansiklopedisi. 9/61. İstanbul: TDV Yay., 1994.

Ağırman, Mustafa. “Hz. Peygamber' in Anneleri”. EKEV Akademi Dergisi, 11/32 (Yaz 2007), 105-124.

Ahmed b. Hanbel. Müsned. y.y.: b.y., ts.

Akbaş, Mehmet. “Hz. Resulullah Döneminde Evlilik ve Düğün”. Derin Tarih Dergisi. Özel Sayı: 5 (2016). 115-119. İstanbul: Turkuvaz Yay., 2016.

Alkan, Seval. Saadet Asrmm Nurdan Anneleri Hanmm Sahabeler. İstanbul: Zafer Yay., 2012.

Apak, Âdem. Ana Hatlarıla İslâm Tarihi (1), Hz. Muhammed Dönemi. İstanbul: Ensar Neşriyat, 2014.

Apak, Âdem. Kur'an'ın Geliş Ortamında Arap Toplumu. İstanbul: Kuramer Yay., 2017.

Arı, Mehmet Salih. "Üsâme b. Zeyd”. Türkiye Diyanet Vakfi İslâm Ansiklopedisi. 42/361-363. İstanbul: TDV Yay., 2012.

Avc1, Casim. “Peygamberliğinden Önce Hz. Muhammed (sav)”. Vahyin Nüzulünün 1400 Yılında Hz. Muhammed 15-17 Ekim 2010 Milletler Arası Toplantı. ed. Ahmet Kavas, 3/127-138. İstanbul: İslami İlimler Araştırma Vakfı Yay., 2011.

Avcı, Casim. Muhammedü'l-Emin Hz. Muhammed'in Peygamberlik Öncesi Hayatı. İstanbul: Hayy Kitap, 2008.

Ayar, Kenan. "Hz. Muhammed' in Çocuklarıla İlişkileri". Dinbilimleri Akademik Araştırma Dergisi 7/1 (Şubat 2007), 81-124.

Aycan, İrfan. "Sa'd b. Bekir". Türkiye Diyanet Vakfi İslâm Ansiklopedisi. 35/372. İstanbul: TDV Yay., 2008.

Aykaç, Mehmet. “Fatıma bt. Esed". Türkiye Diyanet Vakfı İslâm Ansiklopedisi. 12/225. İstanbul: TDV Yay., 1995.

Azimli, Mehmet. Siyeri Farklı Okumak. Ankara: Ankara Okulu Yay., 2015.

Belâzurî, Ahmed b. Yahyâ b. Câbir. Kitâbu Cümel min ensâbi'l-eşrâf. thk. Süheyl Zekkâr vd. Beyrut: Dâru'l-Fikr, 1996.

Belâzûrî, Ahmed b. Yahya b. Câbir. Fưtûhu'l-buildân. thk. Abdulkadir Muhammed Ali. Beyrut: Dâru'l-Kütübi'l-İlmiyye, 2014.

Buhârî, Ebû Abdillâh Muhammed b. İsmâil b. İbrahim el-Cu'fî . Sahîh-i Buhari. thk. Kâsım eş-Şemmâî er-Rifâî. Beyrut: Dâru'l-Kalem, 1407/1987.

Cevâd Ali. el-Mufassal fî târîhi'l-Arab kable'l-İslâm. 10 Cilt. Beyrut: Dâru's-Sâkî, 1422/2001.

Çelikkol, Yaşar. İslam Öncesi Mekke. Ankara: Ankara Okulu Yay., 2014.

Çubukçu, Asri. “Hâlime”. Türkiye Diyanet Vakfi İslâm Ansiklopedisi. 15/338. İstanbul: TDV Yay., 1997.

Dadan, Ayşegül. Ümmü Eymen Hayatı ve Şahsiyeti. Konya: Selçuk Üniversitesi, Sosyal Bilimler Enstitüsü, Yüksek Lisans Tezi, 2009. 
Demil, Emine. Hz. Peygamber'in Risâlet Öncesi Hayatına Dair Rivayetler. Ankara: Ankara Üniversitesi, Sosyal Bilimler Enstitüsü, Doktora Tezi, 2016.

Dimaşkî, Muhammed b. Salih. Peygamber Külliyatı. İstanbul: Ocak Yayıncılık, 2006.

Doğan, Yusuf. “Hz. Peygamber ve Mizah”. Cumhuriyet Üniversitesi İlahiyat Fakültesi Dergisi 8/2 (Aralık-2004), 191-203.

Emre, Mehmet. Büyük İslam Kadınları. İstanbul: Vatan Kitapçılık, 1982.

Ertürk, Hatice Nur. "Hz. Peygamberin (s) Sütanneleri ve Sütanneye Verilmesi”. Siyer Araştırmaları Dergisi 4 (Temmuz-Aralık 2018), 61-68.

Erul, Bünyamin. “Ümmü Eymen”. Türkiye Diyanet Vakfı İslâm Ansiklopedisi. 42/317. İstanbul: TDV Yay., 2012.

Erul, Bünyamin. "Zeyd b. Hârise". Türkiye Diyanet Vakfi İslâm Ansiklopedisi. 44/319-320. İstanbul: TDV Yay., 2013.

Es’ad, Mahmud. Tarih-i Din-i İslâm. haz. A.L. Kazancı - O. Kazancı. İstanbul: Marifet Yay., 1983.

Ezrakî, Ebu'l-Velid Muhammed. Ahbâru Mekke. çev. Yunus Vehbi Yavuz. İstanbul: Feyiz Yay., 1974.

Fayda, Mustafa. “Ebvâ". Türkiye Diyanet Vakfi İslâm Ansiklopedisi. 10/378-379. İstanbul: TDV Yay., 1994.

Fayda, Mustafa. "Fil Vak'ası". Türkiye Diyanet Vakfı İslâm Ansiklopedisi. 13/70-71. İstanbul: TDV Yay., 1996

Fayda, Mustafa. "Hz. Muhammed (sav)". Türkiye Diyanet Vakfi İslâm Ansiklopedisi. 30/479-481. İstanbul: TDV Yay., 2005.

Fiğlalı, Ruhi Ethem. "Ebû Talib". Türkiye Diyanet Vakfi İslâm Ansiklopedisi. 10/237-238. İstanbul: TDV Yay., 1994.

Günaltay, M. Şemsettin. İslam Öncesi Arap Tarihi. Ankara: Ankara Okulu Yay., 2. Basım, 2013.

Halebî, Ali b. Burhaneddin. İnsanu'l-uyûn fî̀ sîreti'l-emîn ve'l-me'mûn el-ma'rifetu bi's-sîreti'l-Halebiyye. Misir: Matbaatu'l-Ezheriyye, 1932.

Hamidullah, Muhammed. "Hilfü'l-Fudûl”. Türkiye Diyanet Vakfi İslâm Ansiklopedisi. 18/31. İstanbul: TDV Yay., 1998.

Hamïdullah, Muhammed. "Hz. Peygamber'in İslam Öncesi Seyahatleri”. çev. Abdullah Aydınlı. Atatürk Üniversitesi İlahiyat Fakültesi Dergisi 4 (Haziran 1980), 327-345.

Hamidullah, Muhammed. İslâm Peygamberi. çev. Mehmet Yazgan. İstanbul: Beyan Yay., 2014.

Heykel, Muhammed Hüseyin. Hz. Muhammed'in Hayatı. çev. Vahdettin İnce. İstanbul: Kitabevi Yay., 2011.

Heysemî, Nureddin. Mecmûatu'z-zevâid ve menbai'l-fevâid. thk. Hüsameddin el-Kudusî. Beyrut: Dâru'l-Kitâbi'l-Arabî, ts. 
93 Mehmet Eser - Adnan Adıgüzel / Hz. Muhammed'in Yetişmesinde Etkili Olan Bazı Kişiler / Some People Who Were Active in The Prophet Muhammad's Upbringing

İbn Hibbân, Ebû Hâtim Muhammed, es-Sîretü'n-nebeviyye ve ahbâru'l-hulefâ, thk. Sa'd Kerîm el-Fakâ. İskenderiyye: Dâru İbn Haldun, 2018.

İbn Hişâm, Ebû Muhammed Abdulmelik. es-Sîretu'n-nebeviye. thk. Mustafa es-Sekâ vd. Beyrut: Dâru'l-Kütübi'l-İlmiyye, 1971.

İbn İshâk, Muhamed b. Yesâr. Sîretu İbn İshâk. thk. Muhammed Hamidullah. Konya: Hayra Hizmet Vakf1 Yay., 1981.

İbn Abdi'l-Berr, Yusuf b. Abdillah b. Muhammed. el-İstîâb fì ma'rifeti'l-ashâb. thk. Ali Muhammed elBecâvî. Beyrut: Dâru'l-Ceyl, 1992.

İbn Kayyim el-Cevziyye. Zâdu'l-meâd fì hedyi hayri'l-ibâd. thk. Şuayb el-Arnaût vd. Kuveyt: Mektebetu'l-Menâri'l-İslamiyye, 1994.

İbn Sa'd, Muhammed b. Sa'd b. Menî́ ez-Zührî. Kitâbü't-Tabakâti'l-kebir. thk. Ali Muhammed Ömer. Kahire: Mektebetu'l-Hancî, 2001.

İbn Seyyidi'n-Nâs, Muhammed b. Muhammed. Uyûnu'l-eser fî funûni'l-megâzî̀ ve'ş-şemâil ve's-siyer. thk. Muhammed el-Îd el-Hadrâvî vd. Beyrut: Dâru İbn Kesîr, ty.

Kandemir, M. Yaşar. "Hatice”. Türkiye Diyanet Vakfı İslam Ansiklopedisi. 16/465-466. İstanbul: TDV Yay., 1997.

Kara, Cahid. "İslâm Öncesi Arap Yarımadasında Bir Kültür Merkezi Cüreş". Hitit Üniversitesi İlahiyat Fakültesi Dergis, 14/24 (2015/1), 23-49.

Keylanî, Mustafa Seyyid. Hz. Muhammed Hayatı ve Ahlakı. İstanbul: Kitap Dünyası Yayınevi, 2015.

Koçak, Zeynep Canan. “Arap Yarımadası'ndaki Ekonomik Şartların Hz. Peygamber'in (sav) Hayatına Ve Hadislere Yansıması”. Bartın Üniversitesi İslami İlimler Fakültesi Dergisi 4/8 (Güz 2017), 72-94.

Köksal, M. Asım. İslam Tarihi. İstanbul: Şamil Yayınevi, 1987.

Kutluay, Abdülaziz. Siyer-u Sahabe Hz. Resulullah'ın Yakınları. Şanlıurfa: İpek Yay., 2005.

Küçükaşc1, Mustafa Sabri. "Sâkif". Türkiye Diyanet Vakfi İslâm Ansiklopedisi. 36/10-11. İstanbul: TDV Yay., 2009.

Mâğlus, Sami b. Abdillah. Siyer Atlası. çev. Abdullah Karakaş. İstanbul: Siyer Yay., 2014.

Mevdûdî, Seyyid Ebü'l-Âlâ. Tarih Boyunca Tevhid Mücadelesi ve Hz. Peygamber. çev. Ahmet Asrar. İstanbul: Pınar Yay., 1984.

Niyaz, Mevlânâ. Kadın Sahabeler. çev. Ali Genceli. İstanbul: Toker Yay., 1971.

Numânî, Mevlânâ Şibli. Sîretü'n-Nebî Son Peygamber Hz. Muhammed. İstanbul: Milli Gazete Yay., 2005.

Öğüt, Mehmed Cemal. İslam Tarihinin Maruf Simalarından Hz. Muhammed'in Dadısı Ümmü Eymen. İstanbul: Bürhaneddin Matbaası, 1941. 
Önkal, Ahmet. “Kays Aylan”. Türkiye Diyanet Vakfi İslâm Ansiklopedisi. 25/91-92. İstanbul: TDV Yay., 2002.

Öztürk, Emine. Hz. Muhammed'in Tebliğ Mücadelesinde Taif Yolculuğu. İzmir: Dokuz Eylül Üniversitesi, Sosyal Bilimler Enstitüsü, Yüksek Lisans Tezi, 2010.

Öztürk, Levent. "Süveybe”. Türkiye Diyanet Vakfı İslâm Ansiklopedisi. 38/183. İstanbul: TDV Yay., 2010.

Sarıçam, İbrahim. "Neccar". Türkiye Diyanet Vakfı İslâm Ansiklopedisi. 32/480-481. İstanbul: TDV Yay., 2006.

Sarıçam, İbrahim. Hz. Muhammed ve Evrensel Mesajı. Ankara: DİB Yay., 2002.

Sezikli, H. Ahmet. “Abdulmuttalib". Türkiye Diyanet Vakfi İslâm Ansiklopedisi. 1/272-273. İstanbul: TDV Yay., 1988.

Şeriati, Ali. Muhammed Kimdir. Ankara: Fecr Yay., 1988.

Şulul, Kasım. “Allah'ın Himayesinde Yetim ve Öksüz Bir Çocuk". Derin Tarih Dergisi. Özel Sayı: 5 (2016), İstanbul: Turkuaz Yay., 9-17.

Taberî, Ebû Cafer b. Muhammed. Tarihu't-Taberî-Tarihu'r-rusul ve'l-mulûk-. thk. Muhammed Ebu'lFadl İbrahim. Kahire: Dâru'l-Maârif, 1969.

Topaloğlu, Bekir. "Âmine”. Türkiye Diyanet Vakfi İslâm Ansiklopedisi. 3/63-64. İstanbul: TDV Yay., 1991.

Uyar, Gülgün. Hz. Muhammed'in Risalet Öncesi Hayatına Dair Bazı Rivayet Farklarınn Tespiti. İstanbul: Marmara Üniversitesi, Sosyal Bilimler Enstitüsü, Yüksek Lisans Tezi, 1993.

Vâkıdî, Muhammed b. Ömer. Kitâbü'l-Meğâzî. thk. Muhammed Abdulkadir Ahmed Atâ. Beyrut: Dâru'l-Kütübi'l-İlmiyye, 2013.

Watt, W. Montgomery. Hz. Muhammed Mekke'de. çev. M. Rami Ayas - Azmi Yüksel. Ankara: Ankara Üniversitesi İlahiyat Fakültesi Yay., 1986.

Yeniçeri, Celâl. Hz. Muhammed'in Ailesi, Köle-Cariye ve Hizmetçileri. İstanbul: Marmara Üniversitesi İlahiyat Fakültesi Yay., 2000.

Zapsu, Abdürrahim. Büyük İslam Tarihi. İstanbul: M. Sıralar Matbaası, 1957.

Zehebî, Şemseddin Muhammed b. Ahmed b. Osman. Tarihü'l-İslam ve vefeyâti'l-meşâhîri ve'l-a'lâm es-Sîretu'n-Nebeviyye-. thk. Ömer Abdusselam Tedmurî. Beyrut: Dâru'1-Kutubi'1-Arabî, 1991.

Zührî, Ebû Bekr Muhammed b. Müslim b. Ubeydillâh İbn Şihâb. el-Meğââ̂. çev. Mehmet Nur Akdoğan. Ankara: Ankara Okulu Yay., 2016. 